\title{
REDES ECLESIÁSTICAS, PROCESOS DE EXTIRPACIÓN DE IDOLATRÍAS Y CULTOS ANDINOS COLONIALES EN ATACAMA. SIGLOS XVII Y XVIII
}

\author{
Jorge Hidalgo Lehuedé
}

\begin{abstract}
Resumen
Se analiza la bibliografía atingente a la extirpación de idolatrías en Atacama colonial (actual segunda región, Chile) y se proponen nuevas hipótesis cotejando la documentación conocida con otra inédita. Se avanza en el estudio de las redes y carreras eclesiásticas, y en las actividades comerciales y de extirpación realizadas por los sacerdotes. Se estudian los equipos sacerdotales que descubrieron cultos idolátricos y huacas en cuatro visitas o campañas de extirpación entre 1635 y 1674. Se proponen tres etapas en la formación del cristianismo atacameño colonial: 1) 1557-1635, en la que la Iglesia y las huacas compartieron similares valores simbólicos; 2) 1635-1650, en la cual los indígenas de Atacama ven al sacerdote como proveedor y otorgador de prosperidad; 3) Siglo XVIII, cuando los atacameños se han apropiado de las principales enseñanzas del cristianismo colonial, pero donde algunos de los atributos de las huacas han sido traspasados simbólicamente al Dios cristiano, a la Iglesia y sus representantes.
\end{abstract}

Palabras claves: idolatrías - huacas - catolicismo atacameño.

\begin{abstract}
This paper analyzes the bibliography related to Extirpation of Idolatries in colonial Atacama (II Region, Chile), and proposes new hypotheses through both well-known and unstudied documents. We make a contribution to the study of ecclesiastic networks and careers, remarking on both extirpations and commercial activities, and studying the priestly teams that discovered idolatry cults and huacas in four visits or extirpation campaigns between 1635 and 1674 . We propose three stages in the formation of Atacameño Christianity: 1) 1557-1635, when the Church and the huacas shared the same symbolic values, 2) 1635-1650, where the Atacameño people saw the priests as providers and carriers of prosperity, and 3) $18^{\text {th }}$ century, when Atacameño people had incorporated the primary teachings of colonial Catholicism, but some attributes of the huacas were symbolically identified with the Christian god, the Church, and its representatives
\end{abstract}

Key words: idolatries - huacas - atacameño Catholicism.

\section{$*$ Introducción ${ }^{3}$}

En la segunda década del siglo XVII se impuso, en el gobierno civil y eclesiástico de Lima, el discurso de que los indígenas de las áreas rurales seguían siendo tan idólatras como en tiempos anteriores a la conquista hispana. ${ }^{4}$ Se aceptaba que la evangelización realizada hasta entonces había sido superficial y engañosa, fruto de una mala práctica de los religiosos así como fundamentalmente por la acción del demonio. Esta desvalorización de los esfuerzos evangelizadores anteriores impidió a los extirpadores percatarse de que parte de aquello que perseguían como supuestamente prehispánico, ya era el resultado de reelaboraciones andinas de la doctrina cristiana inculcada por los sacerdotes, engarzadas con prácticas y creencias religiosas andinas (Estenssoro 2003). Los españoles coloniales concibieron a la religión nativa como pasiva e inmutable y vieron lo sagrado andino en términos de "persistencia". Pero como ha observado Griffiths:

"La religión nativa no era ningún almacén inerte de creencias y prácticas atemporales. Durante el período colonial ni desapareció ni sobrevivió inalterada. En lugar de ello, sufrió adaptaciones fundamentales en un dinámico proceso de auto-renovación" (1998: 24).

En los procesos de evangelización en Lima, estuvo presente desde temprano el tema de la idolatría, referido a aquellos indios que a pesar de haber recibido instrucción religiosa y ser bautizados, continuaban practicando sus cultos de raíz

Recibido: septiembre 2011. Aceptado: enero 2012.

\footnotetext{
1 Proyecto FONDECYT 110013: "Historia de los pueblos andinos de Arica, Tarapacá y Atacama: Las políticas estatales y eclesiásticas y las dinámicas de las comunidades indígenas, siglos XVI-XIX".

2 Facultad de Filosofía y Humanidades, Universidad de Chile. CHILE. Email: jorgehidalgolehuede@gmail.com

3 La mayor parte de los documentos sobre idolatrías en Atacama citadas en este texto - con la excepción de la Probanza de Francisco de Otal y
} 
andina, que en la mentalidad española eran expresión de la adoración al demonio. Los dioses o "ídolos", en el lenguaje hispano, correspondían a veces a tradiciones ampliamente expandidas o compartidas con otros grupos y, en otros casos, a cultos regionales, locales e incluso familiares (Polo de Ondegardo 1916 [1571]; Arriaga 1999 [1621]). La crítica eclesiástica más dura se dirigía contra los "dogmatizadores" o aquellos que eran refractarios al cristianismo, que continuaban rindiendo culto a sus dioses e induciendo a sus comunidades a practicar los ritos tradicionales; igualmente lo era para los "hechiceros" y "supersticiosos", que frecuentemente no se distinguían de los anteriores en las denuncias a idólatras. Para ellos en los concilios limenses se recomendó aplicar castigos rigurosos, como el corte del pelo, azotes, humillaciones, pérdida de bienes y prisión. Sin embargo, a partir de las denuncias de Francisco de Ávila la persecución de idolatrías inició realmente su ins-

otros textos del Archivo y Biblioteca Nacional de Bolivia (ABNB) facilitados por Nelson Castro y Priscilla Cisternas- fueron ubicados por el autor en el AGI el año 2000. Paralelamente el colega José Luis Martínez había ubicado los mismos documentos, por lo que surgió la idea de hacer un artículo en coautoría. Lamentablemente eso no fue posible por las numerosas obligaciones mutuas. Sin embargo, el autor informó de estos documentos y sus contenidos a la comunidad de investigadores en diversas ponencias. Entre ellas: La extirpación de idolatrías en los Andes y sus manifestaciones en Tarapacá y Atacama (Conferencia Inaugural, XVI Jornadas de Historia de Chile, Universidad de Los Lagos, Osorno, 4 de octubre, 2005); Idolatrías en Tarapacá y Atacama, siglo XVII: Nueva documentación (IX Jornadas de Historia Andina en el norte de Chile, Universidad de Valparaíso, 30 y 31 de noviembre, 2005); Curas y redes eclesiásticas: los extirpadores de idolatrías en Atacama y Tarapacá, siglo XVI (X Jornadas de Historia Andina del norte de Chile, Universidad de Valparaíso, Viña del Mar, 8 y 9 de noviembre, 2006); Doctrina, Idolatría y Economía. Tarapacá y Atacama siglo XVII (III Taller de Historia Andina, Universidad de Tarapacá y Proyecto FONDECYT 1071131, Arica, 7 al 10 de enero, 2009); Extirpación de Idolatrías en el corregimiento de Atacama: redes eclesiásticas y cultos andinos coloniales, siglo XVII (XV Jornadas de Historia Regional de Chile: Las historias regionales frente al Bicentenario, Universidad de Tarapacá, Arica, 18 al 21 de octubre, 2010); Cultos andinos coloniales en el corregimiento de Atacama según procesos de extirpación de idolatrías. Siglo XVII (VIII Congreso Internacional de Etnohistoria, Sucre, 26 al 29 de junio, 2011).

4 La bibliografía sobre idolatrías en el siglo XVII es bastante extensa y toca varios aspectos colaterales, algunos de los cuales citaremos más adelante. Por ello mencionaremos aquí solo algunos autores, vinculados al estudio de la idolatría en Lima, tales como Duviols (1971, 1977, 1986); Mills (1994, 1997); Bernand y Gruzinski (1992); Griffiths (1998); Cordero Fernández (2010); Estenssoro (2003). titucionalización, ya que el sacerdote de Huarochirí acusó a sus feligreses indígenas de apóstatas y herejes por continuar practicando su religión prehispánica, pese a haber recibido el bautismo. En 1609, un Auto de Fe realizado en Lima, y que incluyó la quema de ídolos y momias, así como azotes a los idólatras, contó con el apoyo de las principales autoridades civiles y religiosas, contribuyendo a producir un cambio de mentalidad y con ello el diseño de nuevas políticas dirigidas a cambiar el método de la evangelización pasando de la persuasión a la represión. Esto se logró con la creación de la figura de juez visitador o de Visitador General de Idolatrías que recibió Ávila en 1610 y luego otros curas, a quienes se delegaron poderes propios del rango de arzobispo. Esta autoridad les permitía no solo juzgar a los idólatras sino también les daba el derecho de visitar las doctrinas y examinar los conocimientos religiosos y el manejo de las lenguas nativas de los respectivos curas, con la posibilidad de destituirlos (ver, p.e., el título de extirpador de José Caro Mundaca, en el anexo 2 de este artículo). A partir del sínodo de 1613, este sistema de visitas de idolatrías se formalizó en el derecho canónigo siguiendo el modelo general de la Inquisición, ya institucionalizada, aunque con diferencias de procedimientos y dirigido a sujetos distintos (Millar 1998).

El equipo que acompañaba al Visitador General incluía, al menos, un fiscal y un notario. Los acusados de idolatría, a diferencia de los acusados por la Inquisición, tenían derecho a defensa, función desempeñada generalmente por el defensor de indios. Para algunos autores lo que se pretendía era mantener la ficción de un proceso legal. Según Griffiths (1998: 53), el papel de defensor "no precisaba necesariamente de un especialista y en muchos casos se trataba de un mero gesto formal". Sin embargo, Cordero Fernández (2010) argumenta que se trató de un cambio fundamental pues permitió impugnar las acusaciones e incluso carear testigos que en la Inquisición quedaban anónimos, demostrando algunos casos exitosos de estos procedimientos. ${ }^{5}$ Por otra parte, a diferencia de la Inquisición, la extirpación cumplió la doble tarea de servir fines judiciales y de evangelización. Especialmente en una primera etapa, entre 1609 y 1622 , las campañas de los extirpadores fueron apoyadas por un grupo de jesuitas que, paralelamente al juicio,

\footnotetext{
5 En el caso del corregimiento de Atacama, sin embargo, Vázquez de Espinosa (1948 [1629]: 730), no indica la existencia de Protectores de Indios.
} 
realizaban una evangelización intensiva. Sin embargo, en una segunda etapa del proceso de extirpación, entre 1649 y 1670, los jesuitas dejaron de cooperar, probablemente por temor a perder la confianza de los indios (Griffiths 1998; Cordero Fernández 2010). Duviols señala que:

"Las etapas de la visita de idolatrías fueron codificadas en el sinodo de 1613: cuando un equipo llega a un pueblo, el visitador debe publicar el 'edicto de gracia' por el cual se conceden tres días a los indígenas para entregar sus huacas, denunciar a los demás idólatras, hechiceros, etc. Luego se exhiben los ídolos, se manifiestan los hechiceros, y se hace un inventario de ellos. Después se puede proceder a sesiones públicas de abjuración y absolución, seguidas de la cremación de las huacas en la plaza del pueblo y de la destrucción a los adoratorios y templos paganos fuera del pueblo. Por último, se debe aplicar a los 'hechiceros y dogmatistas' las penas previstas por el Concilio III, con el subsiguiente 'apartamiento' de los tales" (Duviols 1986: XXXII).

La riqueza de fuentes para el estudio de las idolatrías en el Arzobispado de Lima creó la impresión, en algunos investigadores, de que no se habían desarrollado estos procesos en otros lugares. Sin embargo, hay autores que han demostrado que el movimiento extirpador se extendió en la jurisdicción del Arzobispado de Charcas (Castro 1991, 1993, 1997, 2009; Draper 2000; Barnadas 1993, 1997, 2004). Barnadas ofrece una excelente síntesis de la legislación charqueña en relación al tema de extirpación de idolatrías. Entre sus disposiciones analiza el Primer Sínodo Paceño (y primero charqueño) que tuvo lugar en 1619 y que estableció los procedimientos básicos contra los idólatras por parte de los doctrineros, así como de los visitadores y jueces de idolatrías. Sin embargo, al mismo tiempo, el sínodo aspiraba a un mayor resultado de la acción catequética y de las homilías de los doctrineros (Barnadas 2004: 84-85).

El Primer Sínodo del Arzobispado de La Plata, celebrado entre 1619 y 1620 , reconocía la baja cristiandad de muchos de los indios y lo poco que aprovechaban las enseñanzas de los curas, advirtiéndoles a renglón seguido, que tuvieran "cuidado de la extirpación de los ritos antiguos e idolatrías". El sínodo delimitaba o prohibía ciertas acciones que podían ser signo de una idolatría encubierta, tales como: a) la celebración de bailes públicos en el día del Corpus Christi, en los que se llevaban niños para ser ofrecidos al demonio, estableciéndose además que esas criaturas no debían llevar pantas (o especies de mantillas) en la cabeza; b) que en la noche de Pentecostés o día del Espíritu Santo, se tocaran tambores a oscuras en la casa de los curacas para invocar al demonio, y que se colocaran "unas maneras de guaras o calzones" a los muchachos que los facultaba para que fueran varones; c) la celebración de ritos en la siembras de chacras; d) el entierro de difuntos con ropas o vestidos, oro, plata o derrame de chicha; entre otras tantas, que el cura debía descubrir por propia experiencia o siguiendo las instrucciones contenidas en el catecismo de 1583 (Méndez de Tiedra 2002: 13-15). Se enfatizaba, además, que no se hicieran "juntas generales de borracheras, porque aquí es donde el demonio coge sus copiosas cosechas" (Méndez de Tiedra 2002: 15; Barnadas 2004: 85-86). También se incluyeron en ese concilio disposiciones para impedir que los curas permitieran las idolatrías de los ancianos que vivían en pueblos viejos y estancias, estableciendose que, por el contrario, debían vivir

“...en el pueblo y reducción principal para su mejor enseñanza $y$ doctrina $[. .]$.$Y con los que se averiguare que son hechiceros o$ supersticiosos se use el rigor contra ellos y sean traídos a su reducción y sean castigados, dándonos primero de ello aviso" (Méndez de Tiedra 2002: 23-24).

El Segundo Sínodo Platense no agregó nada significativo en relación a las idolatrías (Barnadas 2004: 86). En cambio el Primer Concilio Platense de 1629, incorporó nuevas reflexiones y disposiciones de los obispos, que constataban la proliferación de las idolatrías, pidiendo a los párrocos un esfuerzo sistemático de enseñanza religiosa mediante los catecismos aprobados por el Tercer Concilio Limense. Ordenó cambiar una lista de prácticas y se pronunció con fuerza contra los líderes religiosos nativos que se mostraran incorregibles (Barbadas 2004: 86-87). En el Segundo Sínodo Paceño el tema idolátrico estuvo ausente, mientras que, al contrario, el Tercer Sínodo Paceño, realizado un siglo más tarde, reconocía la persistencia idolátrica que se mantenía solapada por la astucia del demonio, denunciándose cultos aparentemente cristianos pero que ocultaban prácticas supersticiosas e idolátricas. En el siglo XVIII, el Tercer Concilio Platense (1771-1773) dedicó una constitución al tema de la idolatría enfocando la mirada en las juntas y bailes de los indios para embriagarse, con los consecuentes resultados en supersticiones e idolatrías. Barnadas (2004: 87-88) se pregunta si tales disposiciones mostraban la persistencia de ese mal o era una prueba de la rutina instalada en la Iglesia dieciochesca. 
Antonio Acosta (1979, 1982a, 1982b, 1987), ha vinculado el inicio de los procesos de extirpación con las actividades comerciales y abusivas que realizaban los curas doctrineros en sus parroquias. En sus afanes por enriquecerse materialmente, éstos entraban en conflicto con líderes étnicos, quienes al reaccionar denunciándolos a las autoridades superiores, eran acusados de idólatras por los curas para acallarlos.

En este contexto, la extirpación de idolatrías constituyó una oportunidad para algunos sacerdotes que vieron la posibilidad de proyectar su carrera eclesiástica prestando servicios como extirpadores. La persecución de idolatrías les permitió revestirse de méritos religiosos ante las autoridades políticas y eclesiásticas, y con ello aspirar a dignidades superiores en los templos o lugares más centrales, de mayor prestigio y de mejor renta. De allí que, antes y después de estos procesos, para muchos de ellos fue una preocupación mantener excelentes relaciones, redes de contactos con las autoridades eclesiásticas e incluso con otros religiosos de otras jerarquías que pudieran ayudarlos en esta línea o testificar por los servicios prestados. ${ }^{6}$ Pudiera pesar en algunos de esos casos que se tratara de curas que carecían de lazos familiares regionales y, por lo tanto, su promoción dependiera fundamentalmente de demostrar sus méritos como extirpadores. ${ }^{7}$ La vía para solicitar este reconocimiento fue por medio de Probanzas o Relaciones de Servicios, donde los testigos eran interrogados a partir de un cuestionario preparado por el interesado. Estos documentos son los que utilizamos, y no corresponden propiamente al testimonio notarial de los tribunales constituidos en Lima de acuerdo al derecho canónico indiano instaurado en esos años. ${ }^{8}$

\footnotetext{
6 Sobre la carrera eclesiástica en la línea de servicios contra las idolatrías, ver Ramos (1992). Esta autora sugiere que, por aumentar sus méritos, el extirpador otorgaba a la idolatría mayores dimensiones diabólicas o heréticas, lo que obliga al historiador a hacer una lectura más crítica de estos documentos. Ver también Acosta (1979, 1982a, 1982b, 1987); Guibovich (1993: 169-240); y Griffiths (1998: 193-233).

7 Sobre carreras eclesiásticas en ausencia de extirpaciones de idolatrías y en la línea de las vinculaciones familiares ver Irigoyen López (2008), quien incluye una extensa e interesante bibliografía sobre el tema.

8 Sobre el establecimiento jurídico de las visitas de idolatrías a partir del Sínodo de Lima de 1613 y su institucionalización y resultados, ver Cordero Fernández (2010).
}

Como se verá más adelante, en el caso de Atacama, así como en Lima (Acosta 1979, 1982a, 1982b, 1987; Griffiths 1998: 60), se puede apreciar que la acción extirpadora quedó en manos de curas locales que incluso actuaron antes de recibir el título formal de Visitador de Idolatrías entregado por su arzobispo. Hasta ahora no hay evidencias en esta región de que los inquisidores se hubiesen constituido en un tribunal formal para juzgar y condenar a los idólatras y hechiceros. ${ }^{9}$ En cambio, sí parece que se dieron misiones evangelizadoras de jesuitas, algunas contemporáneas o paralelas a las visitas de idolatrías, pero no como parte de las mismas (ver ABNB, EC 1650, 17).$^{10} \mathrm{De}$ acuerdo a sus testimonios, en Atacama, eran los mismos extirpadores quienes se encargaban de evangelizar después de destruir a los ídolos en actos públicos.

Se debe al recordado amigo e investigador francés Thierry Saignes la ubicación en el Archivo General de Indias, del primer documento conocido por los investigadores modernos sobre el proceso de extirpación de idolatrías en Atacama (AGI Charcas 92). Thierry tuvo la gentileza de facilitar este documento a José Luis Martínez y éste a su vez a Victoria Castro, quien en su tesis de Magíster en Historia, Mención Etnohistoria, de la Universidad de Chile, utilizó extensamente y transcribió la Probanza de Méritos (1645) de Francisco de Otal, cura propietario de Atacama la Baja con sede en Chiu Chiu (Castro 1997). Fueron profesores patrocinantes de su tesis Rolando Mellafe, inicialmente, y luego Osvaldo Silva Galdames, debido a la enfermedad y fallecimiento del primero. Esta tesis, con algunas adiciones, ha sido publicada como libro en el año 2009. La tesis que guió el trabajo de la autora fue la continuidad de las creencias andinas desde el período prehispánico hasta el presente -lo que no quiere decir que no reconociera la tremenda fuerza del proceso evangelizador y de extirpación de idolatrías-, pero su búsqueda y marco explicativo se orienta en el sentido

9 Éstos se hacía acompañar de un grupo de sacerdotes encargados de la posterior evangelización intensiva que, en las primeras etapas, estuvo generalmente a cargo de los jesuitas (Duviols 1971; Griffiths 1998; Cordero Fernández 2010).

${ }^{10}$ Información de servicios de Francisco de Otal, racionero de la Catedral de La Plata. Véase las declaraciones del jesuita Benito Bravo (fs. 1r, 2v). Agradezco a Nelson Castro por haberme dado una copia de este documento, del cual se incluye una transcripción completa (paleografiada por Priscilla Cisternas) en el anexo documental de este artículo. 
señalado. ${ }^{11}$ Entre los méritos de esta investigación se debe destacar su carácter pionero en los estudios de idolatrías en Atacama; haber analizado en profundidad la bibliografía y la documentación publicada complementaria iluminando el documento de Otal; descubrir una divinidad que sin duda tenía raíces prehispánicas y cuyo culto, al parecer, era probablemente extendido en el sur andino, así como el hecho de ampliar su investigación desde los antecedentes prehispánicos hasta la información etnográfica actual.

Sin duda, en el terreno de las idolatrías del sur andino, este trabajo ha establecido un piso a los estudios regionales que permite seguir avanzando en el descubrimiento de nuevos documentos, para analizar en un lapso cronológico más amplio los diversos esfuerzos por extirpar algunas de las manifestaciones de las religiones nativas en el siglo XVII e incluso para investigar problemas presentes en la mencionada probanza (p.e., el tema de la carrera eclesiástica y las actividades económicas de Otal, que la autora decidió no trabajar en su tesis; ver Castro 2009: 159). Por otra parte, también se pueden explorar hipótesis alternativas con algunos de los nuevos documentos, y es lo que nos proponemos hacer en este trabajo: intentar demostrar los cambios que se manifiestan en los cultos andinos en esta etapa del período colonial, proponer etapas en estas transformaciones de la mentalidad religiosa de los atacamas y poner de manifiesto que el proceso de extirpación en Atacama fue más largo y estuvo integrado por varios equipos de extirpadores.

Otro autor que estudió el proceso de extirpación de idolatrías en Atacama, en el marco de un estudio del clero de Charcas del siglo XVII, por medio de un documento (ABNB, EC 1650, 17), ha sido Draper (2000: 157-161). Esto lo induce a pensar equivocadamente que toda la campaña de Francisco de Otal fue inspirada por el arzobispo Francisco de Borja y que la Visita duró más de un año, como si hubiese sido un solo episodio (Draper

${ }^{11}$ Castro (2009: 17, 22, 38, 55, 111). No obstante, la autora advierte que si bien se aprecian continuidades desde tiempos prehispánicos hasta los actuales, como "la importancia religiosa de los cerros en la Fase Toconce, poco o nada sabemos de la 'parte blanda' de la religión que hay detrás de estas manifestaciones, aun cuando las analogías etnográficas son tentadoras en el sentido de poder otorgarle a estas expresiones un contexto social y económico" (Castro 2009: 111).
2000: 157). Destaca además el autor citado los gastos personales en los que incurrió el Visitador de Idolatrías de Atacama, que incluyeron, probablemente, el pago de otro sacerdote, un notario, la manutención de varios acompañantes, y retribuciones a los delatores:

“...lo que hacía bastante oneroso todo el proceso. Naturalmente, los costos de estas visitas a menudo se los traspasaban a los pueblos indígenas investigados, pero parece probable que, por lo menos en un comienzo, Otal tuvo que cargar con buena parte del costo de la pesquisa. Muchos de los ídolos descubiertos fueron enviados al Arzobispo, probablemente para demostrar la eficacia de la campaña; los sacerdotes nativos responsables de fomentar los cultos paganos también fueron remitidos a La Plata, donde fueron depositados en la Recoleta franciscana. Hasta aquí la práctica siguió el esquema general de las campañas limenses y probablemente se inspiraron en ellas (Duviols 1977: 248-260). Se mantuvo a los sacerdotes autóctonos en un estado de confinamiento, obligándolos a asistir a los oficios del templo. Todo esto se hacía 'por el bien de sus almas', pero evidentemente también servía de una forma de control social" (Draper 2000: 157).

Este es uno de los prismas de la interpretación de Draper, la intencionalidad del control político de la autoridad hispana sobre los indígenas:

“...desde su comienzo la campaña constituía un intento de las autoridades eclesiásticas centrales de La Plata por extender su influencia a los más lejanos rincones y quebradas del Arzobispado; por otra parte el éxito de Otal en desarraigar los objetos de culto de manos de los indios y, aun más patentemente, en enviar a cautiverio a los responsables de estos ritos, implicaba la clara intención política de convencer a los indios que nos les quedaba otra alternativa que someterse a las exigencias que les imponía la cultura dominante" (Draper 2000: 158).

Una segunda fase de la interpretación de Draper se vincula a los aspectos "de una constelación de estructuras ideológicas que señalan las corrientes más profundas de la cultura hispana de la época" (2000: 158). En la campaña de destrucción de los "rastros del culto pagano [...] había una profunda falta de confianza en la propia sociedad hispánica y un amplio sentido de crisis moral que cuestionaba la legitimidad de la empresa colonial" (Draper 2000: 158-159). Además de intentar imponer a los indígenas una obediencia pasiva, se trataba de demostrar a los indígenas y a los propios colonos la superioridad de 
la cultura hispana, idea que en los niveles "profundos e inconscientes de la cultura, era puesta en duda" (Draper 2000: 159). Otra interpretación del autor citado es que todo el ritual que acompañaba al proceso permitía a los curas afirmar su propia autoridad sobre los indios:

"Para afianzar el control sobre los autóctonos habría bastado un simple despliegue de fuerza; pero las campañas extirpadoras llevaban intrínseca la necesidad de apresar también los espíritus de los indígenas. En pocas palabras: era una empresa tan ideológica como política" (Draper 2000: 159).

Es por ello que entendemos, siguiendo a Gruzinski (1991), que esta etapa de la evangelización forma parte de la conquista del imaginario. La interpretación de Draper de las extirpaciones implica también un componente social sobre quien debía prevalecer en la nueva identidad americana en formación, en particular la amenaza que representaba el mundo indio a los criollos, quienes aspiraban a "que la cultura indígena quedara efectivamente sumergida en la cultura hispanoamericana emergente" (Draper 2000: 160). Esta tesis se vincula con el argumento central del libro de este autor en el sentido de que el clero de Charcas era predominantemente criollo, pero que incluía una porción significativa de peninsulares. Pertenecían a la elite de la sociedad colonial y habían recibido una buena formación académica, muchos de ellos ligados a familias del sector social alto de Lima. En este conjunto pocos de ellos tenían una mentalidad "evangelizadora" y "culta", "el clero con una mentalidad prioritariamente religiosa era una minoría; esto sugiere, a su vez, que la Iglesia en general prestaba mayor atención a sus funciones política y social que a la religiosa" (Draper 2000: 161). Por supuesto que el autor admite la existencia de excepciones, pero su idea es que el clero de Charcas era parte integral de la sociedad civil, y como tal buscó

“...mantener la cohesión interna de esa sociedad promoviendo las normas vigentes de conducta moral, ética y religiosa que la caracterizaban. El clero, en general, no aportó un impulso hacia el cambio ni hacia la introspección moral, sino que básicamente funcionó como un factor conservador de la sociedad, que se identificaba con las exigencias de la ortodoxia que caracterizaron a la cultura hispana del siglo XVII" (Draper 2000: 161).

En esta revisión bibliográfica de idolatrías en Atacama es necesario recordar que Barnadas (2004) intentó entregar una visión exhaustiva de las extirpaciones de idolatrías en Charcas y de los religiosos que participaron en ellas. Para Atacama, menciona y reseña las acciones y títulos de Francisco de Otal, Joseph Caro de Mundaca, Juan de Alcalá Olazábal e incluso una breve referencia al proceso del cacique de San Pedro de Atacama, Pedro Liquitaya (Barnadas 2004: 103-107). Sus fuentes son Castro (1991) y Draper 2000, es decir aunque se basó en fuentes secundarias, lo interesante es que trató de integrar esos procesos en el conjunto histórico de Charcas.

En este trabajo nos proponemos, en primer lugar, identificar a los sacerdotes que participaron en las redes eclesiásticas y en las visitas o campañas de extirpación, por lo que también prestaremos atención a sus actividades extraeclesiásticas, como las iniciativas comerciales desarrolladas por Otal, y las de otros sacerdotes que aspiraron a alcanzar alguna promoción. Luego veremos los principales cultos indígenas que se identifican en esas distintas campañas y finalmente trataremos de apreciar en una relación tri-secular los cambios ocurridos en la mentalidad religiosa andina de Atacama, especialmente en lo que se refiere al imaginario en torno a los sacerdotes.

Hay otros temas que no trataremos aquí, pero que están indudablemente unidos a los procesos de evangelización en el área andina, de los cuales son parte las visitas de extirpación de idolatrías. Entre ellos nos referimos a la creación de colegios de caciques y otros procesos educativos (Arriaga 1999 [1621]: 147-148; Duviols 1977: 329-330; Hidalgo y Castro 2008); a los procesos de beatificación de santos en los Andes (Cussen 2005); a las referencias a idolatrías en la visita pastoral de obispos de Arequipa (Hidalgo y Díaz 1985), y a las carreras eclesiásticas en las circunscripciones vecinas, como es el caso de Arequipa y consecuentemente Tarapacá (Marsilli 2002; Hidalgo et al. 2012).

\section{* Redes eclesiásticas y CRonología de las \\ VISITAS O CAMPAÑAS DE EXTIRPACIÓN en Atacama}

\section{Francisco de Otal (1620-1652)}

En 1615 el licenciado Francisco de Otal, clérigo presbítero natural del Reino de Aragón, se encontraba en 
Lima solicitando a la Real Audiencia de la Ciudad de los Reyes el reconocimiento de los aragoneses para pasar a Indias y gozar de los beneficios que poseían los naturales de Castilla. ${ }^{12}$ En 1618 solicitó que la Real Audiencia de Charcas refrendara esos autos otorgados en Lima (Probanza f. 9r). Gabriel de Sande, quien tuvo acceso a los papeles de Otal, "vio y examino es que dicho Racionero es persona noble hijo de padres principales su padre Juan de Otal y su madre Juana Casiñere hijos de algo infanzone [sic] en el Reyno de Aragon" (ABNB, EC 1650,17 , f. 10v). En 1620 inició su actividad pastoral en Atacama (Casassas 1974: 77), y habría permanecido allí hasta su muerte en 1652 , pero lo más probable es que falleciera en la ciudad de la Plata. ${ }^{13}$ En 1622 fue designado Visitador de Atacama la Alta y la Baja y vicario y juez eclesiástico (Probanza, f. 29v, 32 r y 35 r, 37v). ${ }^{14}$ En 1626 logró una provisión real en defensa de los indios de Atacama para que pudieran servir a quien quisieren, sin que los corregidores ni otras personas lo impidie-

12 (AGI Charcas 92, Probanza f. 8v) Aun cuando tenemos copia del original de la probanza de méritos de Francisco de Otal, hemos preferido trabajar con la transcripción publicada por Victoria Castro (2009: 493-571). Se trata de una excelente transcripción, pero la citamos en sí misma para enfatizar nuestra lectura e interpretación del documento. De modo que en lo que sigue adelante cuando nos referimos a "Probanza" estamos haciendo referencia a esa versión del documento.

${ }^{13}$ Castro (2009: 158) sugiere la muerte de Otal en 1652 en Atacama, siguiendo a Casassas (1974: 77), quien señalaba que de acuerdo al Libro de Varias Ojas (Libro Parroquial de Chiu Chiu), en octubre de ese año estaba puesto el trámite para cubrir la vacante producida por su fallecimiento. No obstante de acuerdo a ANB, EC, 1650, 17, sabemos que Otal estaba de racionero de la catedral de la Plata en 1650. Casassas agrega que Otal en 1648 había sido "propuesto y nombrado para una Ración en la Catedral de la Plata, dotada de 1500 pesos anuales, pero tal vez no tomó posesión de dicho cargo, o lo mejoró posteriormente ya que nuevamente fue propuesto y nombrado para otra Ración en la misma Catedral, de acuerdo con otro documento [del AGI] fechado el 26 de mayo de 1651" (Casassas 1974: 77). Por ello se puede sostener que probablemente falleció en La Plata.

${ }^{14}$ El corregimiento de Atacama estaba organizado en dos doctrinas: Atacama la Alta, cuya cabecera y a la vez capital del corregimiento era San Pedro de Atacama; y Atacama la Baja, con capital doctrinaria en San Francisco de Chiu Chiu. La primera incluía los oasis y ayllus circundantes a la localidad de San Pedro y los anexos de Toconao, Socaire y Peine. La segunda comprendía los pueblos de Chiu Chiu y Calama, en el curso medio del río Loa, los de Ayquina y Caspana en la región del Loa Superior y, en la costa, el anexo y puerto de Cobija (Hidalgo 1978). ran. Ese mismo año, como cura coadjutor y futuro sucesor del titular de Atacama la Baja, Francisco Bernal, solicitó al Cabildo de la Catedral del Arzobispado de la Plata que se le diera licencia para dejar el curato argumentando que el sínodo que recibía de seiscientos pesos no le permitía sustentarse. El curato contaba con ochocientos pesos de sínodo de los cuales doscientos se debían pagar al propietario, quien estaba impedido de cumplir su labor eclesiástica (Probanza, fs. 32v, 34v). Además, señalaba que no se encontraba otro sacerdote que supiera la lengua materna de dicha provincia, por lo que se deduce que Otal conocía la lengua kunza, además del quechua y probablemente algo de la lengua de los camanchacas o indios costeros..$^{15} \mathrm{La}$ solución fue entregarle a Otal seis indios camanchacas, para que pescaran para él, obligándose el cura a pagar sus tasas al encomendero (Probanza, fs. 68v, 78r). Esta concesión fue la base del poder económico y de la influencia de Otal más allá de Atacama. Le permitió poner un cura en Cobija (el padre Joan de Uspariche ${ }^{16}$ ), para que administrara los sacramentos, al que le pagaba seiscientos pesos de estipendio de su sínodo, más otros trescientos en alimentos, por lo cual, señalaba, "no me queda otra

${ }^{15}$ La idea de que hablaba kunza se confirma en la opinión del visitador eclesiástico Gabriel de Sande que en 1632 señalaba que Otal "es grande e lenguaras no solo en la lengua general quichua mas empero con muy grandes ventajas en la lengua materna y nativa de este dicho beneficio por lo cual a hecho grandes servicios a dios nuestro señor" (Probanza, f. 23v). En 1641, dos caciques de Caspana testifican que desde que llegó a Atacama, Otal intentó aprender su lengua y que "la sabe con eminencia" (Probanza, $f$. 53r). No obstante en relación a los camanchacas de Cobija, en 1628 Otal declaraba que "aviendome costado muy gran travajo y cuidado el rreducir estos indios camanchacas a que biniessen a la doctrina y supiesen rrezar en lengua de castilla que es la que mas se acomodan por no saver ninguna de las generales quechua ni aymara tuve bien de ponerles un sacerdote" (Probanza f. 78v, 79r. Aquí y en siguientes, el subrayado es nuestro). Es decir él y su sustituto adoctrinaron a los camanchacas en lengua de Castilla. Sin embargo, en 1643, el visitador eclesiástico Diego de Acevedo, señalaba que Otal era persona docta "y Predicador en la quichua y en la lengua materna de los indios camanchacas" (Probanza f.16v, 17r). Pudiera ser que en los 15 años que median entre las dos declaraciones, Otal hubiera aprendido la lengua de los camanchacas, pero también que el testimonio del visitador, por su incapacidad de acreditar los conocimientos lingüísticos de Otal, emitiera un informe superficial tendiendo a exagerar sus méritos.

${ }^{16}$ Licenciado Juan de Usparicho, ver referencia en Casassas (1974: 77). 
cossa mas que algún aprovechamiento que tengo del pescado que me benden los dichos indios" (Probanza, fs. 78v, 79r). Como señala Otal, los indios le vendían el pescado, que habría pagado al precio de venta en la costa, para su sustento. Esto último implicaba su venta a mejor precio en otros mercados más lejanos, que le permitían tener significativas ganancias con las cuales financiaba sus diversas actividades sin necesidad de recurrir al sínodo ni otros ingresos eclesiásticos. Como algunas personas lo inquietaban por ello, pidió que lo ampararan en la concesión de los seis camanchacas en 1628 (Probanza, fs. 79r, 81r).

\section{Primera campaña de extirpación: 1635}

En 1635, en la noche del 23 de junio en la víspera de San Juan, ${ }^{17}$ Otal, acompañado de dos españoles (Juan Caballero ${ }^{18}$ y Juan Martín) y de un negro, sorprendió en una casa de Calama a tres indios viejos en ceremonias idolátricas. En los días siguientes publicó que en no más de tres días los pobladores debían confesar sus idolatrías y que serían perdonados, y si no lo hiciesen los habría de quemar (Castro 2009: 165-167; Probanza fs. 41r, 42v). Con ello logró confesiones masivas e identificó los lugares de culto, quemando numerosos ídolos en una ceremonia en la plaza de Calama. Todos estos antecedentes se originan en una Información posterior, que comenzó en enero de 1641 por iniciativa del gobernador de Atacama la Baja Pedro Vilquibitur, quien por haber tenido noticias de que el Arzobispo de la Plata deseaba reemplazar a Otal por haber sufrido un accidente en 1639 que lo había dejado impedido de una pierna, señalaba que no deseaban que otro religioso ocupase su lugar (Probanza fs. 4lv, 43r, 58r). ¿Se trataría de una acción espontánea del cacique o habría sido inducido por Otal en el momento en que se encontraba presente un

\footnotetext{
${ }^{17}$ La noche de San Juan se asocia en la tradición cristiana a cultos paganos. ¿Sería esa pista de tipo europeo lo que motivó a Otal a iniciar sus persecuciones en un momento calendárico que en sus concepciones era propicio para la brujería y contactos con el demonio? ¿O su acción fue en respuesta a una denuncia que coincidía con ceremonias andinas en la proximidad del solsticio de invierno? ¿O a mbas alternativas se conjugaron?

${ }^{18}$ Juan Caballero, Alguacil Mayor, designado por Otal, debe haber tenido a la fecha 20 años y llegó posteriormente a convertirse en el civil de mayor confianza del sacerdote, en asuntos religiosos y comerciales.
}

visitador eclesiástico que podía dar fe de las declaraciones? A partir de 1639 es probable que Francisco de Otal, por razones de salud y de negocios, fijara su residencia en Cobija.

\section{Segunda campaña de extirpación: 1638}

Tenemos una información muy fragmentaria de este episodio, también encabezado por Otal, como se deduce de la carta del corregidor de Atacama Gerónimo de Contreras, que fue acompañada de otra (que no tenemos), de Juan Caballero, Alguacil Mayor del Santo Oficio en Atacama y estrecho colaborador del sacerdote. En la carta desaparecida, probablemente se aludía a dos situaciones. Por una parte, a una sublevación de los indios de Atacama, posiblemente vinculada al cobro de tributos y, por otra, a la petición de que quitasen la cobranza y administración de los tributos al gobernador Pedro Liquitaya, por temor a irregularidades. Impelido a enterar las cantidades correspondientes, el gobernador indígena no pudo hacerlo, por lo que fue detenido, pero logró huir de la prisión. En el intertanto, fue acusado como "el sacerdote mayor de la idolatria". Se le hizo causa en su ausencia y resultó "gravemente culpado por lo qual [señala el corregidor] le condene a muerte en rebeldía". Se temía además, según información que el corregidor de Atacama entregaba al virrey, que hubiese una alianza entre los atacamas y los indios calchaquíes para eliminar a las autoridades de la provincia (ABNB C 1638, III, 22, núm. 1455, en Estudios Atacameños 10: 74). Si este Pedro Liquitaya es el mismo gobernador de Atacama la Alta mencionado en esa posición en 1591 (ABNB, correspondencia, año 1591, VII, 19, núm. 417), o bien -lo que es más probable - se trataba de su hijo (ya que entre ambas fechas habían transcurrido 47 años), constituye un claro indicio de que esta campaña de 1638 fue una extensión de las actividades extirpadoras hacia la doctrina de Atacama la Alta, y que Otal y sus colaboradores salieron de los límites de su parroquia, probablemente apoyándose en el título de "Visitador de Atacama la Alta y la Baja" así como de juez eclesiástico de Atacama que había recibido en 1622 .

\section{Tercera Campaña de extirpación: 1641}

En 1641 el arzobispo de la Plata le otorgó a Otal el título de vicario y juez de idolatrías en consideración a 
las actividades que ya había realizado en esa dirección (Probanza, f. 18v). En los tres años siguientes, Otal recibió sendas cartas del arzobispo agradeciéndole, por ejemplo, por las "noventa y una presas de pescado congrio"; o por la "cantidad y género de pescado" que le remitiera, señalando que todo había sido recibido "cabal y muy azendrado y bueno"; o "haciendo la estimación que devo por del regalo del atun que trajo el yndio muy sasonado y a buen tiempo y es cosa lindísima". Se menciona también en la correspondencia, la aprobación de lo obrado por Otal al castigar a los ministros de idolatrías que habían huido a los ingenios de la vecina región de Lípez, en particular a Pedro Canerit, quien había sido rapado y azotado, como también a otros que fueron condenados a servir en un convento de por vida. Se aprobaba, también, la condena al clérigo Diego Vargas Machuca, por haber ayudado a uno de ellos a huir a Chile y por impedir el comercio de los indios (Probanza fs. 83r, 9or). Estos datos hacen referencia, claramente, a una tercera campaña de extirpación de idolatrías, probablemente más extensa e intensa que la primera de $1635 .^{19}$

En esta campaña, Francisco de Otal contó con el apoyo del sacerdote Doctor Joseph Caro de Mundaca. Descubrieron que los indios tenían una cueva "donde para sus ydolos y ydolatrias estavan cabezas de leones carneros de La tierra ay cus, coca, chicha, quilaPana y la yervacata todo lo qual lo tienen Para ofrecer a los dichos ydolos" (Probanza, f. 11v, 12r). Señalan, además, que han confesado a más de 1.500 indios e indias:

"Porque todas las confesiones que an hecho de muchos años a esta parte an ssido nulas y les ha cogido todos los ydolos que tenían que son desde el tiempo del inga Los quales a rremitido a su señoria ylustrissima dicho señor arçobispo e ba proçediendo a castigar a los que son cabeças de todas estos ydolatras" (Probanza, f. 12r).

Parecen sorprendentes estos datos después de que en la información de 1641, los testigos indígenas declaraban en relación a los sucesos de 1635, que gracias a la labor

${ }^{19}$ Castro (2009: 170), interpreta a partir de la Probanza de Otal que esta campaña extirpadora había ocurrido con anterioridad a 1633 . Sin embargo, los datos contextuales, así como las evidencias aportadas por ABNB, EC 1650, 17, indican que ocurrieron en 1642. evangelizadora de Otal habían salido de la ceguera y pecado de la idolatría en que estaban y que sus padres les habían enseñado (Probanza, f. 4lr), agregando que los había "sacado de la servidumbre y esclavonia del demonio que los tenia ciegos y engañados con los ritos y serimonias de su gentilismo" (Probanza, f. 45r); y que "desde entonces aca saben estos testigos que todos los indios de este beneficio están desengañados en semejantes disparates y biven como cristianos" (Probanza, f. 56v). No obstante, esta sorpresa pudiera no ser tanta si se considera que esta campaña -como veremos-al igual que la segunda, estuvo centrada en Atacama la Alta y no en la Baja, como aconteció con la primera. Sin embargo, también hay que considerar que las antiguas prácticas no desaparecieron del todo, o se transformaron, y que esas declaraciones apuntaban a levantar los méritos de Otal.

Paralelamente, Otal se preocupaba de sus negocios. En 1642, en Cobija, otorgó un amplio poder a Juan Caballero de Carte y Cardona, Alguacil Mayor del Santo Oficio, nombrado por él mismo, para que lo representara en compras, ventas, cobranzas, pleitos en Cobija, Potosí, La Plata "y otras partes de este reyno de Piru", para que pudiera comprar en su nombre,

“...cuales quiera cantidades de mais harina de trigo sezinas cordobanes vino aceyte e vinagre y otros generos que en cualquier manera llegare a este puerto de Cobija comprándolo para mi y concertándolo de contado o de fiado como le pareciere... $y$ para que en mi nombre esciva y cobre todas y cualesquiera cantidad de pesos ganado coca, vino aseyte vinagre maíz harina de trigo y cordobanes y otros generos que en qualquier manera se me devan y Por qualquier causa o rrasson que ssea y Por qualesquier Perssonas y que a mi venga dirigido y consignado Por mar e Por tierra" (Probanza fs. 2v, 4v).

En 1644 Juan Caballero refrendaba este poder en Potosí y entregaba solo el poder de pleitar a nombre de Francisco de Otal al sochantre de la Iglesia Catedral de La Plata don Andrés Juan Crespo del Bruno, y a Juan Valdés y Antonio González del Pino, procuradores de causa de la Real Audiencia de La Plata, "en todos tres juntos y en cada uno de ellos" (Probanza fs. 2v, 4v). ¿Cuáles eran los pleitos por intereses económicos que sostenía Otal? No lo sabemos, pero podría ser una buena pista para obtener mayor información. 
Coincidente con este poder que refleja las complejas redes eclesiásticas y operaciones comerciales de Otal en Atacama, así como con las regiones circunvecinas, los caciques principales del pueblo de Caspana Diego Mayssar y Pablo Laminir, declaraban en 1641, con un discurso diferente y que terminaría por imponerse en Charcas hacia 1650 -como hemos visto en Draper (2000)-, que Otal no había querido aumentar su caudal sino enriquecer a los indios. Señalaban que antiguamente los habitantes de Atacama eran

"paupérrimos sustentándose solo con algarroba sin comer carne [en cambio] de presente Los dichos indios tienen mulas puercos $y$ ovejas y tratan en trajines y fletes para Potosi con que pagan sus tassas y se visten y tratan como hombres de rraçon" (Probanza, f. 57v).

También don Pedro Viltiquibilti, gobernador de Atacama la Baja, en su nombre y en el de los demás caciques declaraba que Otal los proveía de medicina y había favorecido sus haciendas pues no cobraba por bautizos, casamientos ni entierros, solo lo que voluntariamente quisiera dar cada uno. No vendía vino ni coca y no consentía que otros lo hicieren, ${ }^{20}$ en cambio les vendía mulas que venían de Chile o salía de fiador de ellos, quienes le pagaban con fletes que les daba de sus pescados y acarreo de cordobanes de Chile que luego llevaban a Potosí, "...y con esto an venido muchos nabios y nos han balido los fletes mas de veinte e mill pessos finalmente Le devimos todo Lo que somos" (Probanza, fs. 4ir, 41v).

Sin embargo en estas fechas Otal estaba intentando obtener una prebenda, promoción o nuevo nombramiento en las catedrales de Lima o Charcas y para ello había hecho la probanza de méritos que conocemos. La Real Audiencia de La Plata, en vista de los antecedentes, acordó que "se le puede haçer merçed de una raçión en esta Yglesia o la de Lima o una canongía en qualquiera de las iglesias de estos Reynos en que se descargará la rreal conçiençia de Vuestra Magestad... Plata y marzo 24 de 1645 años" (Real Audiencia de La Plata 2007, vol. 10: 481 ).

\footnotetext{
${ }^{20}$ Compárese con la frase relativa a la coca en los poderes citados anteriormente (Probanza fs. 2v, 4V).
}

\section{* Sacerdotes de la plata, vinculados o TESTIgos de LAS CAMPAÑAS dE Francisco DE OTAL COMO EXTIRPADOR DE IDOLATRÍAS en Atacama}

\section{a. El jesuita Benito Bravo (1644-1650)}

Un conjunto de testimonios a favor de Francisco de Otal complementarios con su probanza corresponde a la información de los servicios del sacerdote, fechada en La Plata en 1650, cuyo documento original fue citado por Draper (2000), sintetizado por Barnadas (2004) y luego ubicado por Nelson Castro, que publicamos en el anexo de este artículo. Este documento, ubicado en el Archivo y Biblioteca Nacional de Bolivia (ABNB), contiene las declaraciones del padre jesuita Benito Bravo, quien practicó misiones evangelizadoras en Atacama en la misma fecha que Otal hacía sus visitas de idolatrías. El jesuita Bravo deja constancia del rechazo que despertaban las campañas de extirpación entre los campesinos y del buen tino de Otal con ellos:

"dize este declarante que no fue tan grande el travaxo que tuvo en la mission que yba haziendo por la buena disposission con que hallava a los yndios y siendo assi que semexantes visitas suelen engendrar odio y rencor en los visitados tubo tan buen modo el dicho raçionero y se supo dar tal maña que sin faltar al buen efecto de su visita" (ABNB, EC 1650, 17, f. 1v).

Por este documento sabemos que Otal había salido de Atacama y se encontraba de racionero de la Catedral de La Plata en 1650. No obstante, Benito Bravo declaraba que conocía a Otal desde hacía seis años, en las provincias de Atacama la Alta y la Baja y en el puerto de Cobija,

"donde anduvo ocupado este declarante en una misión de las que acostumbra la compañia predicando y confesando a todos los mas de aquella provincia y hallo al dicho Licenciado Francisco de Otal en estos tiempos exerciendo el oficio de cura en Atacama La Baja y el de vicario comisionado de la Santa Cruzada y Santo Oficio y visitadory juez de la Ydolatria asi en esta provincia como en la de Atacama la alta" (ABNB, EC 1650, 17, f. 1r).

En consecuencia, Benito Bravo conoció Atacama varios años después que Otal hubiera iniciado su labor extirpadora de idolatrías, en 1635 , y se aprecia que probablemente fue testigo después del inicio de la tercera campaña de 1642 . Su declaración indica que Otal continuó realizando siste- 
máticamente estas campañas, pues Bravo señala que anduvo en los mismos pueblos donde se hicieron las diligencias, y trató con los mismos indios y muchos de ellos habían sido "penintenciados" por Otal. En su declaración el padre Benito Bravo recomendaba a Otal para una dignidad en la catedral de La Plata (ABNB, EC 1650, 17, fs. 2r, 2v).

\section{b. Padre fray Juan Bautista, guardián del convento de la Recoleta}

En la misma información de servicios, este sacerdote declaraba que conocía a Francisco de Otal por más de 30 años y había tenido noticias de sus buenas costumbres y de su labor contra las idolatrías, señalando que

“...entre otras de amonestaçiones que hizo condeno dos de los ydolatras mas prinçipales al serviçio desta santa recoleçion donde vivieron mas de dies año y el dicho racionero llevado de su virtudy christiandad a hecho de veynte y quatro años a esta parte limosna de tres cargas de pescado en cada uno fuera de otras buenas obras que a hecho por lo qual a sido y es estimada su perssona de los prelados y superiores (ABNB, EC 1650, 17, f. 2v).

Recomendaba, además a Francisco de Otal para una dignidad en la Iglesia Catedral de La Plata. De manera que Otal, además de donar pescados salados y/o secos al arzobispo, hacía limosnas de los mismos al convento de los franciscanos, donde habían sido remitidos como servidores de por vida dos "dogmatizadores" o sacerdotes indígenas de Atacama.

\section{c. Fray Rodrigo Manzano, padre lector}

Declaraba conocer a Otal desde hacía unos seis años. Este testigo es el primero en señalar que las campañas de idolatrías fueron financiadas con la hacienda del propio extirpador y que éste no cobraba a sus parroquianos los derechos eclesiásticos. Agregaba que merecía una dignidad por encontrarse además quebrado de una pierna (ABNB, EC 1650, 17, fs. 4V, 5r).

\section{d. Don Miguel de Chalas, secretario y contador del deán y cabildo de la Iglesia de Charcas y receptor del Santo Tribunal de la Inquisición}

Hacía 15 años que estaba en la iglesia de Charcas y había sido secretario de cámara del arzobispo fray Francisco de
Borja, fallecido 14 años atrás. El arzobispo, enterado de que la provincia de Atacama estaba plagada de idolatrías, concedió los títulos para que Otal actuara ampliamente en "las causas de idolatrías y heregias y de otras quales quiera supersticiones y ritos sin reserbar cosa alguna fiando de su gran talento y christiandad el castigo de los complises en dichas culpas". Agregando en su declaración que Otal

“...aviendo corrido toda la provinçia de atacama alta y baxa acompañado de las personas que refiere dicha su petiçion a su propia costa y expensas en que se ocupo mas tiempo de un año descubrió un cresidisimo numero de ídolos en quienes los dichos indios tenían sus adoraçiones de los quales alouna parte de ellos remitió al muy reverendo arçobispo y este testigo los vio remitiendo assi mesmo a los ministros desta falsa ceremonia que venían aser los cavesas prinsipales dellos al convento de los recoletos descalsos desta ciudad para que durantes sus vidas sirbiesen en el" (ABNB, EC 1650, 17, fs. 6r, 6v).

No cabe duda de que se refería a la primera y tercera campañas. Finalmente señalaba que Otal le parecía digno y merecedor de "un asenço de maior estimaçion desta catredal respecto de no aver sido remunerado en premio de sus grandes servicios con mas de solamente la dicha raçion con cuia renta aun apenas se puede sustentar" (ABNB, EC 1650, 17, fs. 7r, 7v).

\section{e. Ignacio de Cepeda y Toledo, cura de Coroncota}

Este sacerdote declaraba conocer a Otal desde hacía 14 años, en las provincias de Atacama, donde

“... este testigo y vio y comunico al dicho raçionero y fue este testigo a la dicha provinçia en ocasión que el dicho raçionero estaba ocupado con grande vigilançia y zelo fervoroso en la extirpaçion de la idolatría y vio este testigo al dicho racionero que en compañia de dies o doçe personas que llebo en su compañía a quienes sustentaba a su costa andubo por toda aquella provinçia por muy fragosos y difíciles caminos inquiriendo y rastreando los ídolos" (ABNB, EC 1650, 17, f. 7v).

Como testigo presencial colaboró con Otal en las ceremonias de extirpación, testimoniando que

“...para el efecto de quemar los dichos ídolos que se hisiere como mas convieniesse para dar exemplo a los indios el dicho racionero 
y este testigo y algunos españoles que se hallaron presentes llebaron la leña como en sus hombros y poniendo en execucion la quema reparo este testigo en la admiraçion que causo a los indios el ver arder aquellas vanas figuras y coligio el desengaño que tuvieron y lo acertado de la acción en la enmienda de los dichos indios los quales vian que el poder que les avian atribuido era fingido pues los avian visto reducirse a unas zeniças solamente lo que les predicava y rrepetia el dicho racionero y assi mismo sabe que su vida es religiosa y muy exemplar de grandissima caridad asi con sus pobres indios como con los caminantes a quienes socorría con toda la liberalidad y vio este testigo que aun pobre henfermo le dio aun la capa que traia puesta demás de averze dado silla freno y mula y averze aloxado en su aposento mismo" (ABNB, EC 1650, 17, fs. 8r, 8v).

Las declaraciones de Cepeda ponían énfasis en el celo religioso, extirpador y evangelizador de Otal, a la vez que destacaba cómo aquellas figuras idolatradas fueron destruidas sin mayores consecuencias para los españoles y que ante los ojos de los indígenas habían perdido el prestigio que tuvieron antaño. ¿Pero significaba aquello que las creencias indígenas o "supersticiones" en la mirada hispana, habían desaparecido, o que se habían transformado?

\section{f. Gabriel de Sande, clérigo presbítero maestro de ceremonias en la Iglesia Catedral Metropolitana de La Plata, fue Visitador General del Arzobispado}

Gabriel de Sande declaraba haber conocido a Otal hacía más de 40 años en Lima. Si estaba en lo cierto, Otal habría llegado a esa capital en torno a 1610, pero es poco probable que tardara cinco años en solicitar que se le reconocieran los derechos de que gozaban los aragoneses en Indias. Por ello, y tratándose de un recuerdo de memoria de Sande, es probable que su conocimiento de Otal no se remontara más allá de los 35 años. Sin embargo, sus recuerdos se extendían más atrás que los otros testigos y entre ellos sacaba a luz que el arzobispo fray Gerónimo Méndez de Tiedra había elegido a Otal como cura y vicario de Atacama y como visitador general de esa provincia, en consideración a su virtud, letras y suficiencia. Luego, mencionaba que había visitado Atacama en tiempos del arzobispo fray Francisco de Borja, como visitador general (1640). ${ }^{21}$ Al llegar a Cobija

\footnotetext{
${ }^{21}$ Probanza, f. 37 v. El 26 de enero de 1641, en Cobija, Gabriel San-
}

pudo apreciar la estima de que gozaba Otal entre indios y españoles:

“...que dicho Racionero en treinta años que avia exercido en aquella provincia de atacama la baja oficio de cura y vicario avia sido tan inculpablemente y con tan christiano proceder que le llamaban el padre de aquella tierra y el que como un apostol avia atendido solo a la redusion de infinitos Yndios que viviendo antes como brutos animales los avia vnido y agregado a la vida politica y christiana y siendo muy pobres y necesitados dicho Racionero, con su pobre caudal y posible los avia alentado y puesto en la ocupacion y exercicio de el tragin de mulas y de la pesquería para asi con su trabaxo socorrer las provincias de Lipes y chichas de pescado de la mar de que totalissimamente carecian dichas provincias en tiempos de adviento y quaresmas" (ABNB, EC 1650,17 , f. 9v).

Sande tenía razón respecto a los 30 años de Otal en Atacama, aun cuando sus recuerdos parecen ser de 1641. Sin embargo, es importante su memoria de que Otal era considerado como padre de la tierra e incluso como un apóstol (un representante y buen discípulo de Cristo, santo y milagroso) que no solo había puesto a los indígenas en vida cristiana, sino también los había enriquecido con sus actividades comerciales. Simbólicamente, Otal empezaría a aparecer ante los españoles y especialmente ante los mismos indígenas, como un proveedor de bienes espirituales y materiales.

Sande mencionaba también la generosidad de Otal con los viajeros que venían de Chile al Perú y viceversa a quienes daba lo necesario e incluso avíos para sus viajes. Atacama, además de ser remota y aislada era tierra de frontera con los indios calchaquíes, lo que sumado a la ausencia de españoles, explicaba que las idolatrías estuvieran muy arraigadas en esa provincia según le había señalado el entonces cura de Atacama la Alta, el maestro Juan de Alcalá. Por otra parte, agregaba que Otal había estudiado la lengua local o kunza para favorecer la evangelización.

\footnotetext{
de, como visitador general, aceptó la solicitud de efectuar una información a favor de Francisco de Otal (Probanza, f. 25v). El 20 de febrero de 1641, Gabriel Sande firmó su sentencia favorable, en la visita secreta en contra de Francisco Otal y Joseph Caro Mundaca en el puerto de Cobija. Todas las referencias a Sande en la Probanza son de inicios de 1641.
} 
Los testimonios de los seis curas indican que Francisco de Otal gozó del apoyo de una compleja red eclesiástica en La Plata, formada por sacerdotes de varias órdenes, algunos de los cuales lo acompañaron en sus campañas y otros lo apoyaron desde las secretarías del arzobispado, o en terreno como visitadores eclesiásticos. Ello fue posible por un conjunto de razones, entre otras su fama de generosidad, de que no cobraba las obvenciones eclesiásticas a sus feligreses, de que entregaba regalos o limosnas de pescado a conventos y prelados, así como especiales donaciones a los arzobispos; actividades que no eran contradictorias con abastecer comercialmente de pescado a varias provincias altiplánicas durante las fiestas religiosas así como en otras épocas del año. Se había construido un prestigio de hombre bueno, religioso y de gran fervor evangelizador, que para ello había aprendido las lenguas locales, además de predicar en quechua; que cumplía con sus tareas sacerdotales, incluido el apoyo a enfermos y desvalidos; que tenía recursos suficientes para mantener a varios eclesiásticos y a las expediciones extirpadoras; que había tenido éxito en descubrir y destruir numerosos ídolos y, además, era considerado un personaje que había traído la prosperidad a los indígenas de una provincia apartada y pobre. El impacto de Otal en la vida material y en la nueva evangelización de los atacameños había sido fundamental. Sin embargo, dentro de Atacama, el sacerdote no actuaba solo. A continuación veremos quienes eran algunos de sus colaboradores, y otros que continuaron con las campañas después de él. Dejaremos para el futuro el análisis de los visitadores eclesiásticos.

\section{* Curas de Atacama que colaboraron con Francisco de Otal}

\section{Joseph Caro de Mundaca (1639- 1691)}

Existe información sobre Joseph Caro Mundaca en el Libro de Varias Ojas (libro parroquial de Chiu Chiu) publicado por Casassas (1974: 78), y sintetizada por Castro (2009: 161). En la probanza de Francisco de Otal (1645), hay referencias suyas a partir de 1639 en su labor complementaria a la del sacerdote en Atacama la Baja, ${ }^{22}$ y en las

\footnotetext{
${ }^{22}$ Los caciques de Caspana declaraban que desde que Otal se había quebrado la pierna contaba con la compañía de "un sacerdote muy onrrado y virtuosso y Principal en los pueblos de chio chio calama
}

propias informaciones de Joseph Caro Mundaca (AGI, Charcas 96, 21, 1660). Casassas (1974: 78), señala que después de su actuación en Chiu Chiu, le fue encargado desde 1666 el curato de San Pedro de Atacama, y que habría fallecido en 1691 después de postular, sin éxito, a diversas dignidades en la catedral de Plata.

En las "Informaciones de José Caro de Mondaca" de 1660 se incluye copia de un documento de 1633, según el cual este sacerdote recibió en Santiago el título de Comisario Predicador de la Bula de la Santa Cruzada, título de tipo honorífico que no involucraba salario alguno, aun cuando estaba destinado a recaudar fondos para los grandes gastos de la guerra contra los infieles (AGI, Charcas 96, 21, 1660 fs. 14r, 18r). Lo interesante de este título es que nos permite saber que ya entonces tenía el grado de doctor. ${ }^{23}$

Las "Informaciónes" de Joseph Caro de Mundaca, entonces, corresponde a 1660, ocho años después de la muerte de Otal y seis antes de asumir en San Pedro de Atacama. En ese documento se describe como presbítero y doctor, natural de la ciudad de La Serena (Reino de Chile), hijo legítimo del Tesorero Pedro Páez de Mundaca y de doña Mariana de Villarroel y nieto del capitán Pedro Fernández de Villarroel, quien fue uno de los primeros conquistadores y pobladores del reino (AGI, Charcas 96, 21, 1660 f. 2r). En el escrito señala:

“...desde mis primeros años segui el estudio de las letras en la vnibersidad de Santiago de chile a donde reçevi el grado de doctor en santa theolojia - y aviendo venido a este Reyno del peru ya saserdote en este arçobispado fui cura catorce años en dos veçes en atacama la baxa con vitilidad y enseñança de los naturales por saver su lengua materna con eminençia y por estos serviçios el Reberendo arçobispo don frai francisco de borxa me

y Caspana", en referencia a José Caro de Mundaca. En tanto, Otal administraba los sacramentos "a los indios Pescadores y all corregidor y esPañoles" que residían en Cobija (Probanza fs. $58 \mathrm{r}, 58 \mathrm{v}$ ). ${ }^{23}$ La Universidad de Santiago de Chile, donde Caro Mundaca obtuvo su grado de Doctor en Santa Teología puede tratarse de una de las dos universidades conventuales con sede en Santiago. La primera fue la Universidad de Santo Tomás, de los dominicos fundada el 19 de agosto de 1622, y donde se podía postular a los grados de bachiller, licenciado, maestro y doctor. La segunda universidad conventual fue la de los jesuitas, que nació hacia 1623 con un curso de artes y otro de teología. Ver Bravo Lira (1992); Mellafe et al. (1992). 
embio horden y comision expressa, para que como su vicario juez visitador extirpase la ydolatria de aquellos indios y lo hiçe con exsesibo trabajo y rriesgo de la vida decubriendo cinco ydolos o guacas en que idolatraban y mochaban Y las deribe y asole, prendiendo y castigando a los ministros de aquella suprestiçion todo a costa mia continuo trabajo de quatro meses no solamente en el gasto de mi persona sino con ministros y gente que lleve, para el efecto y seguridad por ser todo frontera de guerra del enemigo calchaquí con que los yndios de aquella provinçia se reduxeron al berdadero culto y crehencia como lo estan oy, por averles quitado la rais de sus ydolatrias y por aver muchos por bautisar de hedades mayores los enseñe y bautise como todo consta, de los rescaudos que presento y despues el Reverendo arçobispo don frai pedro de obiedo me nombro por su visitador general, de todo su arçobispado y juez de la ydolatria de que resultaron los mismos efectos, y en todos estos tiempos me e portado con toda desençia y decoro, conforme el estado saserdotal, y del grado de mis letras sin aver apeteçido ni conseguido ningun premioNi ocupacion de curato de provecho por aver sido mi vocasion la referida y para que su magestad y Real çonsejo honrre mi persona y serviçios como lo desea y manda" (AGI, Charcas $96,21,1660$ fs. 2v, 3v).

Por esta razón, Caro de Mondaca solicitó que se le recibiera información y que el fiscal informara "como soy digno y mereçedor de que se sirba de Presentarme en vna de las dignidades o canonjías de lima o desta ciudad, en que recibire merçed con justicia" (AGI, Charcas 96, 21, 1660 f. 3v). La petición fue acogida en la ciudad de La Plata el 19 de enero de 1660. Unos días más tarde, la Real Audiencia acordó que el informe reflejaba sus méritos, sin embargo había recibido otro "que se le a echo de mezclarse este sacerdote en algún trato y granjería con publicidad en la Villa de Potosí, Vuestra Magestad se servirá de proveer lo que fuere más de su servicio; cuia cathólica y real persona guarde Dios como la christiandad ha menester, Plata 31 de henero de 660 años" (Real Audiencia de La Plata 2007, vol. 10: 566).

Otro antecedente que no se establece en esta información, fue la razón para dejar Chile e instalarse en el Arzobispado de La Plata. En Chile dejaba redes familiares aparentemente poderosas. En Atacama se puso bajo el alero eclesiástico y económico de Francisco de Otal en Chiu Chiu, doctrina que no ofrecía ingresos significativos, lo que indica que debió ser en aquellos años un hombre bastante joven, sin recursos y sin influencias en esta circunscripción arzobispal, a pesar de su alto nivel de estudios. Aunque Otal solo era licenciado, probablemente le favorecía ser de origen europeo y con habilidad para los negocios comerciales y para tejer redes eclesiásticas. Por otra parte, José Caro de Mundaca declaraba haber sido cura de Atacama la Baja dos veces por 14 años. Sabemos que se encontraba en Chiu Chiu como cura interino y que entre 1639 y 1642 realizó diversas inscripciones en el Libro de Varias Ojas (Casassas 1974: 78), de modo que es difícil señalar en qué años cumplió esos catorce que dice haber servido en Atacama, antes de 1660.

Uno de los testigos de esta información, el maestro Gabriel de Sande, presbítero, dijo que siendo juez visitador del arzobispado en 1638, visitó la provincia de Atacama donde era cura José Caro de Mundaca, dándole aprobación a sus procedimientos y en especial a la extirpación de idolatrías (AGI, Charcas 96, 21, 1660 fs. 6r, 6v). Sin embargo, este testimonio no parece creíble en cuanto a la fecha, dados los antecedentes anteriores y bien puede tratarse de un error de Sande. Otro testigo, el capitán Antonio de Cevallos declaró que conocía a José Caro de Mundaca desde hacía muchos años y lo tenía por bueno, docto y ajustado sacerdote y que la causa de que no tuviera otros curatos mayores y provechosos había sido por no haberlos apetecido, pasando con lustre, calidad y decencia en la villa de Potosí, siendo amado y querido de todos. Otros testigos confirman que en los años cercanos a 1660 José Caro de Mundaca había servido de cura en Potosí (AGI, Charcas 96, 21, 1660 fs. 8r, 9r).

En el documento en cuestión se transcribe su nombramiento como juez eclesiástico y visitador de idolatrías por el arzobispo de Charcas, Fray Pedro de Acevedo en 1648, para todo el obispado, atendiendo a la entera satisfacción y mucha confianza que tenía en José Caro de Mundaca por su santo celo y "lo mucho que obro y trabaxo en destruir Los ydolos que avia en la provinçia de atacama" (AGI, Charcas 96, 21, 1660 f. 1or). ${ }^{24}$ El poder eclesiástico que se le entregaba era considerable, ya que podía citar y visitar a todos los curas del arzobispado, así como las iglesias, parroquias, ermitas, hospitales, cofradías y otros lugares píos. Podía revisar los testamentos, mandas, libros parroquiales, etc. Debía hacer cumplir

\footnotetext{
${ }^{24}$ Incluimos transcripción de Patricio Cisternas de este nombramiento en el anexo 2, fs. 10r, 14r.
} 
las constituciones sinodales del arzobispado de acuerdo a lo dispuesto por el Concilio de Trento y el Limense de "ochenta y tres". Tenía poder para examinar a los curas y clérigos en el conocimiento de las lenguas indígenas como en las materias morales y suspender a aquellos que no tuviesen la suficiencia debida. Podía solicitar a los eclesiásticos títulos de sus órdenes, grados y licencias con las que vinieron a estos reinos. Podía percibir los derechos e instrumentos que como visitador general le pertenecían. Respecto a las idolatrías se señala que era el pecado que más ofendía a Dios pues era quitarle la adoración debida a su divina majestad y darla a los ídolos (AGI, Charcas 96, 21, 1660 fs. 10v, 12v). Por ello se entregaba a José Caro de Mundaca la visita y conocimiento de las causas de idolatrías, supersticiones, hechicerías y brujerías. Debía derribar "guacas mochadores [sic] y otros en que lo vsan levantando en los tales Lugares cruzes y a los dogmatistas y maestros de enseñar la dicha ydolatria que no la confesaren y pidieren misericordia la usara con ellos y los absolverá en el fuero interior de la consiençia" (AGI, Charcas 96, 21, 1660 fs. 12v, 13r).

\section{Juan de Alcalá de Olazábal: 1663}

Contamos con una información de oficio de Juan de Alcalá Olazábal de 1663. Lamentablemente se trata de un documento que se encuentra en mal estado, por ello transcribiremos el parecer de la audiencia del año 1565 que sintetiza sus informaciones:

\section{"Señor}

[al margen] 1663 a 1665

Audiencia de Charcas Ynformacion

En conformidad de cedulas de Vuestra Majestad se ha hecho ynformacion de los servicios y meritos del Maestro Joan Alcala Olaçaval dizen los testigos de publico y notorio que es hijo legitimo del Capitan Joan de Alcala y doña Beatriz de Olaçaval que sirvió en los alborotos que huvo en la villa de potosí en tiempo de los Vicuñas con aprovacion de las justicias fue colegial real en el de San Joan Baptista de esta ciudad donde se graduo de Maestro en artes y siendo sacerdote fue cura de atacama donde se ocupo en la predicacion de los naturales y descubrioles ídolos, y asimismo fue cura de Santa Isavel y de chocaia y despues del de porco y al presente lo es del pueblo de Caiça donde es vicario y por las visitas que se le an hecho se ha conocido su buen proceder como parece de la informacion a esta audiencia le parece que Vuestra Majestad le podra hacer merced de una prebenda en una de las iglesias del tucuman paraguai o buenos ayres.- Vuestra Majestad mandara lo que fuere servido cuia catolica y Real persona guarde dios como la xptiandad ha menester plata 30 henero de 65" (AGI, Charcas 97, 5, 1663; Real Audiencia de La Plata 2007: 578).

¿Cuándo sirvió Juan de Alcalá Olazaval en Atacama? Casassas no lo registra en el Libro de Varias Ojas. Sí aparece su nombre como testigo en la probanza de Francisco de Otal en varias ocasiones. En 1641 fue testigo en la información solicitada a favor de Otal por Pedro Viltiquibilti en Cobija en la que se presenta como cura propietario de Atacama La Alta (Probanza fs. 67v, 68r). Fue testigo también en la visita eclesiástica que el bachiller Diego de Vargas Chacón hizo a Otal en Chiu Chiu en 1639 (Probanza f. 16v). Gabriel de Sande menciona en su declaración a favor de Otal en 1650 que Juan de Alcalá, cura de Atacama la Alta, le hizo un informe sobre las razones que facilitaban las idolatrías en Atacama (ABNB, EC 1650, 17, f. 1or). Se puede suponer entonces que Juan de Olazával coincidió, al menos por un tiempo con Otal y es posible que se hubiera involucrado en su actividad extirpadora, como parte de las redes y servicios comunes que se prestaban entre los sacerdotes de dos sectores limítrofes y pertenecientes a un mismo corregimiento.

\section{* Cuarta campaña de extirpación de IDOLATRÍAS}

\section{Domingo Suero Leiton de Rivera: 1674}

Las visitas de extirpación de idolatría en Atacama no se extinguieron con el fallecimiento de Otal y colaboradores. Otros sacerdotes, como Domingo Suero Leiton de Rivera, hacia 1677, lo sustituyeron en su función de pesquisa de los cultos religiosos de los atacamas. De acuerdo con el Libro de Varias Ojas, este sacerdote recepcionó los bienes de la iglesia de Chiu Chiu en su calidad de cura propio de la misma el 26 de abril de 1671, extendiéndose su ministerio hasta el 6 de septiembre de 1685 (Casassas 1974: 78).

Sus informaciones de 1677 nos permitirán completar estos datos. De acuerdo a los documentos incluidos en la Información de Domingo Suero Leiton de Rivera, en el libro de bautismo de la Iglesia Mayor de la villa de Potosí, 
que comienza en 1636, se registra la partida de bautismo siguiente:

"En Potossi a veinte y nueve de junio de milly seisçientos y treinta y seis años Bautisse puse, oleo y chrisma, a Domingo Suero Leiton de Rivera hijo legitimo de Joan suero Leiton y de Doña françisca de Riveray fueron sus padrinos jorxe gonsales y Cathalina Sanches y lo firme// el Lizensiado Bernardo de Alfaro" (AGI, Lima $263,9,1677$, fs. 10v, 11r).

Se puede suponer entonces que el año de bautizo coincide con su año de nacimiento. Las informaciones de este sacerdote registran los siguientes documentos: Título de cura de la doctrina de Copoata, en Chayanta, otorgado al bachiller Domingo Suero Leiton, presbítero, en razón de haber vacado por muerte del propietario Don Sebastián de Aguilar, en La Plata a 28 de noviembre de 1665 (es decir, cuando era un joven sacerdote de 29 años); Certificación de dar fe de la posesión del cargo de cura interino de San Juan de Pocoata a Domingo Suero Leiton de Rivera por Don Pedro Aricoma y Don Joan Ayra Ariuto, gobernador y alcalde del pueblo, por ausencia de corregidor y su teniente, Pocoata 6 de diciembre de 1665; Título interino de cura del pueblo de Sicasica, por haberse dictado causa criminal contra el licenciado don Gaspar de Céspedes Villaroel "cura y vicario del venefisio de sicasica por el desacato que tubo con la justicia Real de esta Ciudad, Y el escándalo que con ello a causado en la rrepublica y para que aya quien sirva El dicho Beneficio durante la dicha causa" (dado en La Plata el 21 de febrero de 1667); Título de vicario del pueblo de Sicasica, por el mismo motivo señalado en el título de cura (dado en La Plata el 22 de febrero de 1667); Título de Comisario de la Santa Cruzada del pueblo de Sicasica el 28 de febrero de 1667; Título de cura interino de la doctrina de Luribay, por encontrarse el cura titular bachiller don Pedro de Portugal y Navarra en La Plata "al seguimiento de la caussa de capítulos que tiene pendiente en esta audiencia arçobispal". Se señala que a la fecha Domingo Suero Leiton de Rivera era cura propietario del beneficio de Churumata y que se encontraba "en aquel paraje en negocios que tiene", fechado en La Plata el primero de diciembre de 1667; Comisión para proceder en los capítulos del cura de Luribay (AGI, Lima 263, 9, 1677, fs. 1r, 5r); Título de cura en propiedad de Atacama la Baja: incluye tres cédulas reales, una de 1578 para que no se compela a los indios a ofrecer por las misas, que esto debe ser voluntario, otra de 1588 para que los curas no sean tratantes ni mercaderes, la tercera de 1558 para que los curas no persuadan a los indios enfermos a testar a favor de ellos o de la iglesia. En este título se incluían los deberes y derechos del sacerdote. El título otorgado era de cura de Atacama la Baja, Cobija y anexos, y estaba fechado en La Plata en 29 de enero de 1671 (AGI, Lima 263, 9, 1677, fs. 5v, 8r). En Potosí, en virtud de este nombramiento como cura de Atacama se le "dio colassión y canonica ynstitusion por ympocision de bonete clerical" (AGI, Lima 263, 9, 1677, fs. 8r, 8v). Se adjunta también, título de juez y vicario de Atacama la Baja, entregado el 29 de enero de 1671; se incluye sentencia que dictó el licenciado don Julian de Ibarra, en la causa de visita y pesquisa secreta que le es muy favorable a Domingo Suero Leiton de Rivera, dada en los Lipes el 18 de diciembre de 1672; se incluye testimonio de haber quitado ídolos en 1674, y Fee de vida o de la buena salud de Domingo Suero Leiton de Rivera, entregada en San Francisco de Chiuchiu, 7 de octubre de 1674 (AGI, Lima $263,9,1677$, fs. 9r, 10v).

\section{* Cultos andinos en Atacama colonial}

\section{Cultos regionales descubiertos por Francisco de Otal en 1635}

Como señalamos, uno de los méritos de Victoria Castro fue el haber desentrañado la traducción del nombre de uno de los ídolos de Atacama y con ello avanzar en una cierta caracterización, a nivel regional, de la divinidad en cuestión, Sotar Condi, el ídolo quemado en la plaza de Calama por Otal, cuyo nombre, con la ayuda de diversos diccionarios de lenguas andinas, la autora traduce como "picaflor" (Castro 2009: 227). Un testigo indígena lo describe como

“...a quien todos los indios de estas provincias teníamos por dios teniéndolo nuestro Padre [Otal] en la mano vestido de cumbe con su pillo y Plumas en el de oro y Pajaro flamenco nos hizo una plática" (Castro 2009: 525).

Otros ídolos quemados en esa ceremonia por Otal fueron "de Chio Chio llamado quma quma y a otro de Ayquina llamado Socomba y a otro de Caspana llamado sintalacna" (Castro 2009: 525). Vale acotar que toda esta campaña se desarrolla en la jurisdicción de Atacama 
la Chica. En el caso de Sotar Condi, Castro explora los elementos simbólicos que podrían estar representados en el picaflor y cómo su iconografía y nombre aparece en diversas circunstancias andinas. ${ }^{25} \mathrm{La}$ idea de un pájaro que vence a la muerte, por su costumbre de invernar o de aparentemente morir y luego resucitar en la primavera cuando ha florecido la vegetación, es un elemento que lo podría vincular simbólicamente a lo sobrenatural. Por otra parte el colorido de su plumaje tornasolado, lo podría relacionar al sol y al Inka, en cuyos depósitos se encontraban grandes cantidades de plumas de colores de este género de aves. Luego su iconografía en las gigantescas representaciones de aves en Nasca (Perú), donde la población actual cree que "son propiciatorias de la llegada del agua y, tal vez, hace más de mil años, los nasquenses lo asociaron a la fertilidad de la tierra y la germinación de sus cultivos, beneficiando una producción en un territorio extremadamente árido" (Castro 2009: 229). También el nombre del picaflor: quenti en quechua, se asocia a un barrio del Cusco que estaba en dirección al Collasuyu. A partir de estos antecedentes, la autora concluye que se trataría de una divinidad de carácter regional, pero que su ámbito podría ser más amplio (Castro 2009: 239). En el caso de los otros ídolos de Atacama, el análisis de los diccionarios no le permitió llegar a propuestas concluyentes (Castro 2009: 239-246).

Es evidente, que la limitación de la probanza de Francisco de Otal, como fuente, no permite avanzar, por el momento, a un conocimiento mayor de los mitos de la época de la extirpación en Atacama asociados al concepto de una divinidad de este tipo. En todo caso la descripción del ídolo sostenido en la mano por Otal, pareciera indicar una figura de pequeño tamaño - probablemente similar a las miniaturas enterradas junto a las ofrendas humanas de los santuarios de altura-, vestido con ropas finas incaicas o cumbi (Murra 1975, 1978), portando emblemas como el pillo o pillu (cinta o cordón cefálico) y plumas de parina (Martínez 1995) de esa misma tradición, lo que podría indicar que en este apartado rincón de los Andes algunos rasgos de la religión imperial no habrían desaparecido del todo.

Por otra parte, para el caso de Cobija, la documentación vinculada a Francisco de Otal deja en evidencia el culto

\footnotetext{
${ }^{25}$ No obstante no aparece en la iconografía de Atacama, información que agradezco a Helena Horta (2011, com. pers.).
}

a los cerros que, como en toda la ideología extirpadora, se vincula con la adoración al demonio, del mismo modo que en localidades como Socaire, una línea de ceque pasaba sobre el cerro Socompa (6031 m.s.n.m.). Este cerro, señala Castro, es hoy una divinidad tutelar de ese pueblo, invocada en las ceremonias de limpia de acequias" (2009: 217 y 244). ${ }^{26}$

\section{Los cultos idolátricos descubiertos por José Caro de Mundaca en la segunda extirpación de Otal, 1642}

En 1659 José Caro de Mundaca como cura y vicario del pueblo de San Francisco de Chiu Chiu, de Atacama la Baja, solicitó hacer información de cómo

“...el año de mill seisçientos y quarentay dos por el mes de abril por horden que tube del yllustrisimo señor Don frai francisco de Borja del Consejo de su magestad arsovispo de la ciudad de La Plata fi [sic] al pueblo de San Pedro de Atacama San Lucas de toconao Santiago de ssocaire provinçia de atacama la alta y en ella con mi predicassion y maña descubrí en dicho pueblo de San Pedro vn ydolo llamado tocoly otro, en el aillo sequitur de piedra que estava puesto en vna bobeda en sus andas y asimismo, distrui y queme todos los ydolos y mochaderos que avia en dichos pueblos castigando y destruiendo Los ministros dellos y asimismo Bautise mas de sien personas de entre anboz sexssos de ochenta y noventa años que estavan con nombres de cristiano por ynformaçion y diligençias que dello hiçiese y prendi a francisco ttupidiare ministro prinçipal de la dicha ydolatria y lo rremiti presso con el ydolo de Bettere para que su yllustrissima lo castigase y todas estas dilixençias y muchas leguas que andube que serian hasta ochenta a mi costa y gaste mucha platta en ello poniendome a rriesgo de la vida por estar el pueblo de Santiago de ssocaire mui lejos y ser frontera de enemigo calchaqui" (AGI, Charcas 96, 21, 1660 fs. 18v, 19r).

Las declaraciones de testigos, hechas en Chiu Chiu ante el maestre de campo Pedro de Figueroa, corregidor de Atacama, y ante dos intérpretes, permiten ampliar un poco el relato contenido en esta solicitud de informaciones. El primero de los testigos fue Don Pedro García Lasso, gobernador de la provincia, indio ladino en la lengua española, quien dijo que en el año 1642 vio llegar a la provincia a José Caro de Mundaca en compañía

\footnotetext{
${ }^{26}$ Mayor información sobre los cultos a las montañas y limpia de acequias puede verse en Bartel (1986 [1957]); Castro y Varela (1994); Castro y Aldunate (2003).
} 
“...del Lisençiado francisco Otal cura propietario que fue de esta provinçia el qual traya orden y comision del yllustrisimo y rreberendisimo señor Don frai fransisco de borja arsovispo que fue de la ciudad de la plata para haser las diligençias que rrefiere la dicha petizion y por su compañero y quadjutor llevo consigo al dicho Doctor Don Joseph Caro de Mundaca y Diego de Leon y a dionisio garçion y a frai juan machado del orden de san agustin con los quales y este testigo fue como ynterprete fueron al pueblo de san Pedro de atacama la alta y començando a haser las diligençias de saver donde estavan o tenían escondido los ydolos de que llevaban notiçia vio este testigo que el dicho $L i$ sençiado fransisco Otal y el Doctor Don Joseph caro Mundaca mandaron juntar, todos los yndios de los pueblos de atacama $\mathrm{La}$ alta en la ygleçia Donde les estubieren haçiendo cada uno de por si una exortaçion en la misa que este dia se selebro despues del evangelio disiendoles con todo amor y caridad en el serbissio de ambas majestades predicandoles La doctrina cristiana y que no avia mas que vn solo dios verdadero a quien avian de alavary no ydolos y que el que supiese de alguno se lo dexasen que desde luego los perdonavan declarando la verdad y que de no haçerlo ansi prosederian al rrigor que pedia semejante casso, a todo lo qual se hallo Presente este testigo y como tal vio que en el pueblo de san pedro de atacama detras de la ygleçia del allaron un ydolo llamado tocol y después de esto descubrieron a otro ídolo de piedra negra su mal dura en el aillo ssiquitur el qual dicho ydolo hallaron puesto en vna bobeda en sus andas y vio este testigo que los dichos Lisençiado francisco otal y el dicho Doctor Don Joseph caro de Mundaca quemaron los mochaderos y el ydolo que llamavan tocol en la plaça y el otro de piedra con mas otro ydolo que se hallo los quales llevo este testigo a la ciudad de la Platta con los papeles y rrecaudos que en esta rrazon se escrivieron al dicho señor arsovispo" (AGI, Charcas 96, 21, 1660 fs. 2or, 21v).

Señala, además, que se detuvo a muchos indios que fueron desterrados a otros pueblos. Del mismo modo vio bautizar a muchos indios viejos. Después de eso la comitiva regresó a Calama para volver a salir nuevamente al pueblo de Toconao, frontera con los indios calchaquíes. Pedro García Laso declaró tener 46 años.

Otro testigo fue don Juan Catacata, gobernador de la provincia de Atacama la Alta, ladino en la lengua española. Declaró que vio en abril de 1642 la campaña de extirpación de José Caro de Mundaca y Francisco de Otal. Señala que después de la pesquisa, los extirpadores hallaron detrás de la iglesia “...vn ydolo debajo de tierra que algunos yndios Le llama Bantocol [sic] y deçía que era Dios y serca de este paraxe como seis quadras hallaron otro ydolo en el aíllo sequitur de piedra el qual estava puesto en vna bobeda y en vnas andas [...] y castigaron muchos yndios complises [...] prendiendo el dicho Doctor a fransisco tupichare ministro prinçipal de la dicha ydolatria y lo rremitio presso a Chuquisaca para que su yllustrisima lo castigase" (AGI, Charcas 96, 21, 1660 fs. 22v, 23r).

Don Fernando Viltipocpo, natural de San Pedro de Atacama la Alta y segunda persona de ese pueblo, confirma en general lo señalado, y agrega que José Caro de Mundaca fue cura de Chiu Chiu durante muchos años y un año en el de San Pedro (AGI, Charcas 96, 21, 1660 f. 24v). Don Pedro Guacastote, cacique principal del ayllu Solo, agrega respecto a Tocol que

“...sus antepassados lo avian escondido y que era donde yvan a mochar y haçer adoraçion a este ydolo el qual aviendolos sacado vio este testigo que fue debajo de tierra en vn gueco della y en vnas andas puesto y luego este buelto y parte y lugar Donde estava lo mando quemar publicamente desenganandolos del herror en que vivian y los tenia el demonio siegos y apartados de la berdadera fee como se la predicava y creiesen solamente en vn solo Dios Berdadero" (AGI, Charcas 96, 21, 1660 fs. 25v).

Finalmente Martín Catacata, alcalde de naturales de la provincia de San Pedro de Atacama, agrega el siguiente relato:

“...vio que el dicho Doctor y xente española y dicho cura fueron detras de la ygleçia de dicho pueblo y mando cavar en vn paraxe descubrio vn gueco de tierra vaçia Donde hallo en preçensia de los demas vn ydolo que dixeron los yndios que su nombre era ttocol, y que sus antepasados los avian dexado alli de que tenian notiçia y el bulto del vno que fue de este luego al punto lo mando quemar en la plaça publica" (AGI, Charcas 96, 21, 1660 fs. 27r, 27v).

La referencia al "bulto", puede tratarse de una momia de un antepasado que se encontraba en aquella cámara, o al ídolo vestido o envuelto en tejidos, que me parece lo más probable.

El o los ídolos de Sequitor y Beter, según José Caro de Mundaca, el primero de piedra negra, ubicado en una bóveda y también sobre andas, debió o debieron haber sido 
particularmente interesantes como para que se enviara el segundo como una clara evidencia de la idolatría de Atacama la Alta al arzobispo de Charcas, junto al "ministro principal" de idolatrías Francisco Tupichari, quien mantenía vivo o habría revitalizado el culto a estas huacas.

En lengua atacameña "Tockol" significa "hondo, hondura, quebrada”; "Tockor: Hondo" y "Toockor: zanja” (Vaïsse et al. 2006 [1896]: 34). En aymara Ttokho es "Ventana, y también qualquier agugero en la pared que no pafa de banda a banda"; "Alacena en la pared" y "Ttokho ttokho vraque: Tierra de muchos hoyos (Bertonio 1984 [1612]: 161-162). En quechua la voz "Ttokoy huasi se traduce como "casa de muchas alazenas" (González Holguín 1952 [1608]: 344) ¿Podría tratarse de una divinidad femenina vinculada con la fertilidad? (ver Rostworowski 1998, II: 58-59).

La relación de Tocol con la iglesia de San Pedro es intrigante. Por una parte parece que los antepasados intentaron esconder la representación material de esta divinidad, probablemente prehispánica, guardada en una bóveda de donde podía ser llevada en andas en fiestas cúlticas. Se habla de ídolo de piedra y de bulto, lo que indica una figura tridimensional probablemente ornada con textiles indígenas y otros objetos de culto como plumas, lo que explica que fuera posible quemarlo. La cercanía de la iglesia pudo haber sido una buena táctica para esconder un ídolo bajo las narices de los conquistadores sin que fuera detectado. Por otra parte existe, fuertemente, la posibilidad que ese lugar fuera un mochadero prehispánico, un centro religioso, sobre el cual se erigió la iglesia cristiana. Ambas alternativas no son necesariamente excluyentes y hacen pensar en un espacio colonial doblemente ritualizado en la mentalidad andina de Atacama, donde la tradición prehispánica se oculta bajo el mismo espacio sagrado del culto cristiano. Puede ser que los primeros constructores de la iglesia supieran, sin haber conocido el ídolo, que ese era un lugar ritual y de adoración de los atacameños. Desde luego, el Primer Concilio Limense (1551-1552) estableció en la Constitución Tercera, "que las guacas sean derribadas, y en el mismo lugar, si fuere decente, se hagan iglesias". Se señalaba, además, que no solo se debían hacer templos cristianos, sino también derribar las huacas como lugares de culto al demonio pues, de conservarse, se convertirían en un incentivo para que los indios cristianos retornaran a sus antiguos cultos. Para evitar este estorbo se ordenaba construir sobre ellos iglesias o erigir una cruz (Vargas Ugarte 1951: 8-9). En efecto, en las disposiciones entregadas a los extirpadores de idolatrías en 1660 en Charcas, estaba el mismo concepto: "hara la dicha visita y con conosimiento de causa de las ydolatrias superstiçiones hechiserias y brujerías y los lugares para hacerlas los derrivara guacas mochadores y otros en que lo vsan levantando en los tales Lugares cruzes" (AGI, Charcas 96, 21, 1660 fs. 12v, 13r). Vargas Ugarte (1951: 9, nota 3) recuerda que San Gregorio Magno ordenó a los monjes que pasaron a convertir a los ingleses, que destruyeran los templos paganos, pero después cambió de idea y mandó destruir solo sus ídolos, pues convenía que los templos bien construidos fueran purificados con agua bendita, con nuevos altares donde colocar reliquias y poder así pasar del culto al demonio al servicio de Dios. Pareciera que esta práctica se generalizó en Europa y también con las mesquitas en España. Agrega el autor que "esta doctrina algunas veces se puso en práctica en el Perú, como puede verse en el templo del Sol del Cusco, pero no siempre" (Vargas Ugarte 1951: 9). Barnadas (2004: 93) llama a estas práctica el "método de sustitución". Algunos datos parecen indicar que fue más frecuente de lo pensado por Vargas Ugarte con respecto a los emplazamientos y direcciones de las huacas. Por ejemplo, las chullpas o torres funerarias de la fase prehispánica de Toconce, en la región de Atacama, no contenían restos humanos, lo que hizo pensar a los investigadores que su uso era para el culto a los cerros y a los antepasados. Analizaron las direcciones de las ventanas o aberturas de estas construcciones y comprobaron que enfrentaban montañas sagradas. Del mismo modo las capillas y santuarios cristianos actuales enfrentan los cerros dominantes (Castro y Aldunate 2003: 76; Berenguer et al. 1984: 84-87). Estos antecedentes nos hacen pensar que efectivamente los constructores de la iglesia de San Pedro sabían que la construían en un lugar sagrado para los atacameños, pero no que éstos ocultaban allí a Tocol en una bóveda, casi bajo el altar cristiano, el que se mantuvo en la memoria de los atacamas, y había quienes le seguían rindiendo culto en ritos que no conocemos.

No se puede desvincular este conjunto de bóvedas donde estaban estos ídolos con un párrafo que ya hemos citado y que ha sido comentado en extenso por Castro (2009). Los extirpadores descubrieron que los indios tenían una cueva "donde para sus ydolos y ydolatrias estavan cabezas de leones carneros de La tierra ay cus, coca, chicha, 
quilaPana y la yervacata todo lo qual lo tienen Para ofrecer a los dichos ydolos". ${ }^{27}$ Tampoco se puede olvidar las descripciones de Vivar, de que los habitantes de Atacama tenían en sus casas un aposento principal donde tenían las sepulturas de "sus bisabuelos, abuelos, y padres y toda su generación" y que acostumbran "a enterrarse con todas las ropas, joyas, y armas que, siendo vivos, poseía, que nadie toca en ello" (1966: 14). Es decir las casas eran habitaciones, así como templos y sepulturas generacionales. En algunas descripciones arqueológicas de tumbas $y$, por otra parte, en costumbres etnográficas de los siglos XIX y XX en la región de Atacama, Latcham confirma las observaciones de Vivar. En relación a Lasana y San Pedro de Atacama observa que

“...los muertos se enterraban en las casas mismas, en sepulturas cavadas en los pisos de las habitaciones y a menudo forradas en piedras o lajas. En algunos casos, cuando los barrancos formaban uno de los muros de la habitación, se habría en ellos una especie de gruta, para colocar alli el muerto, tapándola después con una pirca o muro de lajas" (Latcham 1938: 63).

La tecnología funeraria también permitía la construcción de cementerios con tumbas "ampollares", cuya entrada superior más estrecha se sellaba con palos atravesados, esteras y arena. Del mismo modo se construían en Chiu Chiu galerías, o

“...verdaderas cavernas cilindricas de tres o más metros de profundidad, cuya abertura no está por encima, sino por un lado y el acceso a ella es por un plano inclinado. El techo, de $80 \mathrm{~cm}$. a un metro de espesor, está formado por la tierra sin remover, encima del pozo. La sepultura empieza por un zancón de piso inclinado en el frente del cual se ha cavado el pozo o caverna. El diámetro de la excavación es de 2.5 mts. a 3 mts. En el fondo, hay, a veces un descanso o galería elevada en todo el contorno, sobre el cual se colocan las momias en cuclillas, envueltas en ponchos o frazadasy junto a ellas el ajuar fúnebre. En algunas de las sepulturas, en vez del descanso se ha socavado una galería de unos $50 \mathrm{~cm}$. en toda la circunferencia y en ella se han colocado los cadáveres. Al parecer, estas sepulturas eran mausoleos de familia, porque en ellas se suelen encontrar varios cadáveres de ambos sexos, párvulos y adultos" (Latcham 1938: 61).

\footnotetext{
${ }^{27}$ Probanza, fs. 11v, 12r. Ver, al respecto, los comentarios, comparaciones e interpretaciones de Castro (2009: 246-287).
}

El autor citado agrega además observaciones etnográficas. En Chiu Chiu seguían existiendo mausoleos familiares en la época que escribía, donde se llevaba a los familiares agonizantes, que eran puestos sobre una mesa redonda donde se dejaban además comidas, bebidas, ropas, joyas y objetos de uso personal del enfermo.

"Se reúnen los deudos y con llantos, bailes y cantos le ayudan a 'bien morir', acontecimiento que en semejantes condiciones no debe demorar mucho. Constatada la muerte, acomodan el cadáver en posición sentada, con la barba descansando en las rodillas y los brazos alrededor de las canillas. En esta postura lo envuelven en mantas sujetas con cordeles de lana y lo dejan sentado en la mesa rodeado de ofrendas. La entrada de la sepultura la dejan cerrada con ramas, tierra y piedras.

Al aniversario de la defunción, que llaman el 'cabo de año', se vuelve a abrir la sepultura para renovar las ofrendas y este rito lo efectúan con nuevos llantos, bailes y cantos.

Cuando se enferma de muerte otro miembro de la familia se repiten estas ceremonias, sentando al moribundo al lado del cadáver primero y así sucesivamente hasta que se llena la mesa.

En San Pedro de Atacama, rigen costumbres parecidas, algo modificadas, pero que en el fondo demuestran el mismo estado de paganismo. Los indios de los aillos, casi de pura sangre, son nominalmente cristianos y sepultan sus muertos según los ritos de la iglesia católica. Pero, al día siguiente, sacan el cadáver nuevamente y hacen nuevos ritos a la usanza de sus antepasados. Estos son casi idénticos a los observados en Chiu Chiu, solo, en vez de efectuarse en la sepultura, se hacen en la morada del difunto.

Sientan el cadáver en una mesa redonda, rodeado de comestibles y bebidas traídos por los asistentes como ofrendas. Desde la mañana hasta la noche, lloran, cantan y bailan, lamentando al muerto. A la oración, suponiendo que el difunto ya no quiere comer o beber más, los que ayudan al duelo se banquetean con las ofrendas en son de fiesta, la que dura una noche, dos o tres, según la cantidad de viandas y sobre todo de licores, dando término al duelo, solamente cuando no queda más que comer o beber. Terminadas estas ceremonias vuelven a enterrar al muerto" (Latcham 1938: 63).

Concluye Latcham reforzando la idea ya formulada en su texto, que las costumbres que subsistían de los atacameños demostraban "que, en el fondo, son tan paganos 
como sus antepasados y que han asimilado, muy poco la religión y la cultura europeas" (Latcham 1938: 63). Es decir, en su visión y con los antecedentes que tenía, la historia colonial había dejado pocas huellas en el mundo de las creencias atacameñas, concepto que esperamos haber contribuido a superar en este artículo y en los muchos años que hemos dedicado a la historia andina colonial. ${ }^{28}$

Las momias de los antepasados, llamados mallqui en quechua (palabra que también significa semilla), así como la huanca, una piedra que se ponía en las chacras, aluden a las vinculaciones simbólicas entre antepasados y fertilidad, reproducción social y tierra proveedora, como también a los soportes materiales de un mundo animado por fuerzas y entidades subterráneas protectoras y peligrosas (Duviols 1986; Bouysse-Cassagne 2008: 331). ${ }^{29}$

¿Fue éste el significado de estas divinidades de tradición prehispánica para los atacamas? En la información de Francisco de Otal de 1650 encontramos una pista en el discurso o prédica de éste, previo a la quema de los ídolos, que alude a los poderes que se creían asociados a estas huacas. En efecto, el cura Ignacio de Cepeda y Toledo, que se encontró presente en ese acto, recuerda que Otal habría dicho "que los demonios les persuadían y aver quitadoles la aprehencion en que el demonio los tenia que por medio de los ydolos les desia que si no los adoraban no tendrían hijos ni fruto en sus cosechas y otros engaños semejantes" (citado por Draper 2000: 158). De acuerdo a esto, habría una fuerte vinculación simbólica entre los cultos a las divinidades prehispánicas y la reproducción de la sociedad, pues éstas propiciaban su fertilidad y la de sus cultivos. Al desaparecer estos cultos, ¿a quién o quienes se transfirieron esas potencias? Es probable que una parte de ellos se renovara o recreara siguiendo la matriz andina, pero es también probable que las tradiciones cristianas se revistieran del legado prehispánico en un nuevo orden cósmico o un sistema religioso creativo y dialéctico donde la mera aculturación resulta una explicación insuficiente.

\footnotetext{
${ }^{28}$ Ver la recopilación de trabajos publicados desde 1971, algunos en coautoría con diversos colegas, en Hidalgo (2004).

${ }^{29}$ Santo Tomás (1951 [1560]) traduce mallqui o mallquina como "planta para plantar"; González Holguín (1952 [1621]: 212), registra mallqui como: "La planta tierna para plantar" y "qualquier árbol frutal"; Bertonio (1984 [1612]: 212), incluye mallqui como "planta para trafplantar".
}

\section{Cultos idolátricos descubiertos en Atacama la Baja por Domingo Suero Leiton de Rivera en 1674}

Nos parece importante transcribir de la información de Domingo Suero Leiton de Rivera, la parte relativa a la identificación de otros ídolos:

\section{[Al Margen] "Testimonio de aver quitado ydolos"}

"En testimonio de verdad Martín Peres de estrada notario de visita yo don Josseph de la torre y salassar escrivano del Rey nuestro Señor certifico doy fee y testimonio de verdad a los que el presente vieren como aviendo ydo a los pueblos de Lassana, Caspana y aiquina jurisdision de la provinçia de atacama La vaja desde este pueblo de san françisco de chio chio de dicha provincia en compañia del Bachiller Domingo Suero Leiton de Rivera cura y vicario de dicho pueblo puerto de Cubija y sus anejos Le vi sacar tres ydolos el vno en el dicho pueblo de Lassana en forma de un platillo quadrado de madera de algarobo con dos figuras de ximios en cuio hueco le echavan comidas las primeras que los yndios de dicho pueblo cogian en sus sementeras a quien ofresian adorassion, Y el otro en el pueblo de Caspana a manera de lagarto de la mesma madera con la voca avierta al qual le ofresian piedras de varios colores de pedernales $y$ polvos de colores y davanle adorassion en Vn alto serro que mira al de potossí en el dicho pueblo del ayquina saco el tersero ydolo de en medio de un caudaloso rrio que estava colocado en Vna peña que estava en la mitad de el, y la bañavan las aguas por entrambos lados a este ydolo segun dixeron los casiques le rendían adorassion y culto llevando el prinsipal Governador en las manos Vna olla nueba yotras veses cargandola en las espaldas y llena de mais y ba la yndia mas ansiana con vn palito sutil y delgado tocandole y en llegando que llegavan con esta seremonia al rrio quebravan la olla en la dicha peña y levantando el grito a voses desian Caiatunar, que en su lengua materna dissen lo que en nuestro ydioma Hispanico buena cosecha para conservasion de la extirpasion de dichos ydolos yo el presente escrivano en compañia del dicho cura y vicario fui a los paraxes Referidos por caminos muy agrios y passe por vna cordillera tan aspera con peligro conosido de la vida por los huracanes y nieves que son tan continuas que de dia y de noche caen, nebando sobre sus empinadas cumbres continuamente caminando a veses por los passos estrechos y peligrossos a pie muchas leguas comiendo el dicho cura Raises de junquillo yerba con que se sustentan Los miserables yndios de dicha provinçia a quienes reduxo y hizo que avominassen sus supertisiones predicandoles la fee de Dios Ynstruciendoles en los prinsipales misterios de nuestra santa fee, en lo qual estan firmes conosiendo sus herrores y veneran con grande efecto a jesuchristo y a su madre santísima acudiendo todos con grande devosion al 

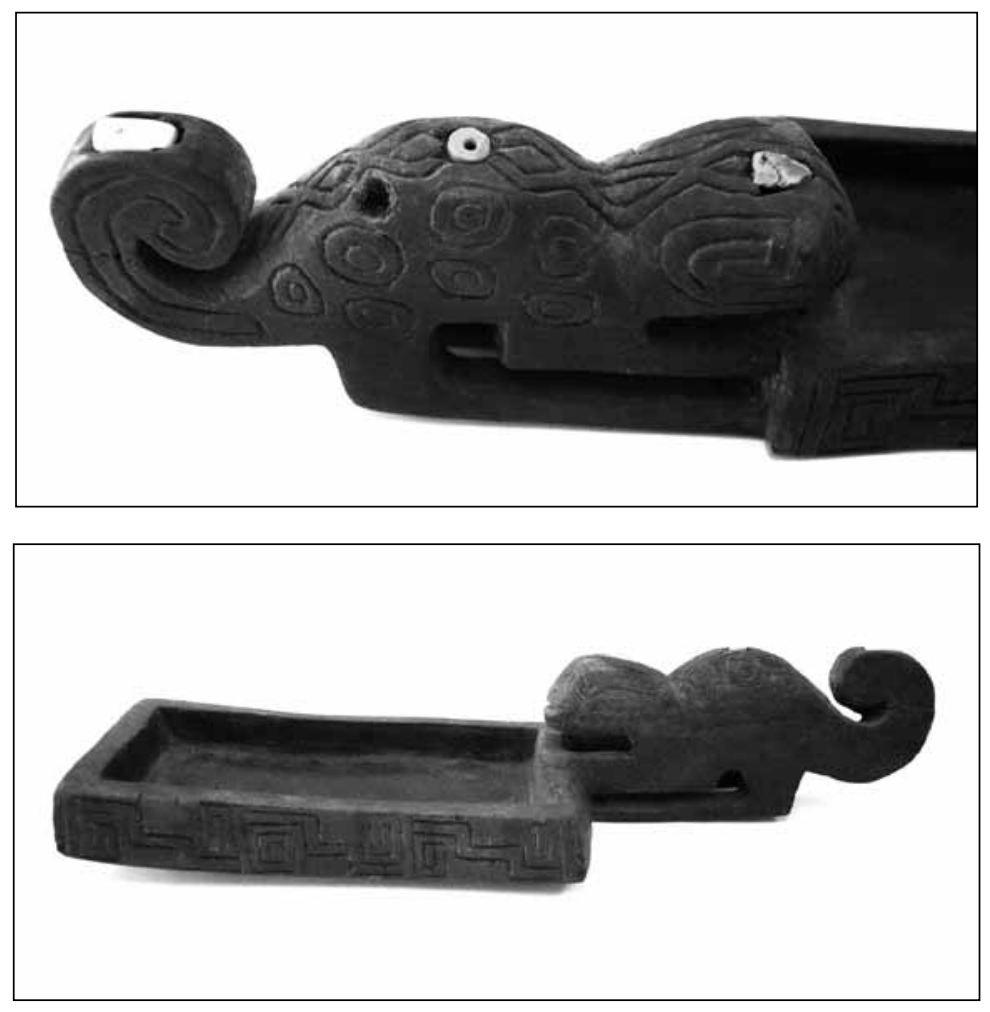

Figura 1 a y b. Tableta prehispánica que parece responder a la descripción colonial. Se trata de una imagen de felino, originalmente dos en esta pieza; sin embargo, una de sus figuras se fracturó, por lo que el canto de la tableta fue limado (Instituto de Investigaciones Arqueológicas y Museo R.P. Gustavo Le Paige, tumba 2568 de Quitor-6; fotografías de Helena Horta).

templo a cantar en su lengua e imnos y alabanssas a Rey y rreina tan esclaresida esmerandose en el adorno y culto de las ygleçias de dichos pueblos en los quales a fabricado Los que estavan caidos que son tres a expenssas de las cortas obensiones que persive y para que conste Lo Referido de pedimento del susso dicho doy el pressente en dicho pueblo de san francisco de chiochio en veinte y siete y siete [sic] días del mes de septiembre de mill seisçientos y setenta y quatro años siendo testigos el maestro de campo Don Bartolome Velarde Corregidor que a sido de dicha provinçia y el maestro de Campo Don Antonio gutierrez caro su susessor corregidor de ella y el Capitan Pedro de chaves morejon alguaçil mayor nombrado de dicha provinçia pressentes = Paso ante mi y en fee de ello Lo signo y firmo en testimonio de verdad derechos quatro rreales foxa Don Joseph de la Torre escrivano de su Magestad" (AGI, Lima 263, 9, 1677, fs. 9v, 10v).

Concentraremos nuestros comentarios del documento en los cultos indígenas de acuerdo a como fueron registrados por el notario.
Respecto al primero de los ídolos, encontrado en Lasana, la descripción de su forma como "un platillo cuadrado de madera de algarrobo con dos figuras de simios en cuyo hueco le echaban comidas" nos indica que se trataría sin duda de un objeto arqueológico cuya función había sido completamente transformada en el ritual religioso. Este tipo de objeto fue conocido originalmente, en la literatura arqueológica, como "tableta de rapé", nombre inadecuado para un artefacto donde los atacameños prehispánicos ponían sustancias alucinógenas que aspiraban por la nariz utilizando tubos. Algunos de ellos corresponden a piezas magníficamente talladas. Por las características de su forma e iconografía, la arqueóloga Helena Horta ha identificado esta pieza, descrita como del estilo circumpuneño, cronológicamente posterior a la cultura Tiwanaku (Horta 2008, 2012). Lo interesante es que en este caso, a nuestro juicio, las tabletas dejaron de ser parte de un complejo alucinógeno para integrarse en una parafernalia distinta vinculada con un ritual de fertilidad de los 

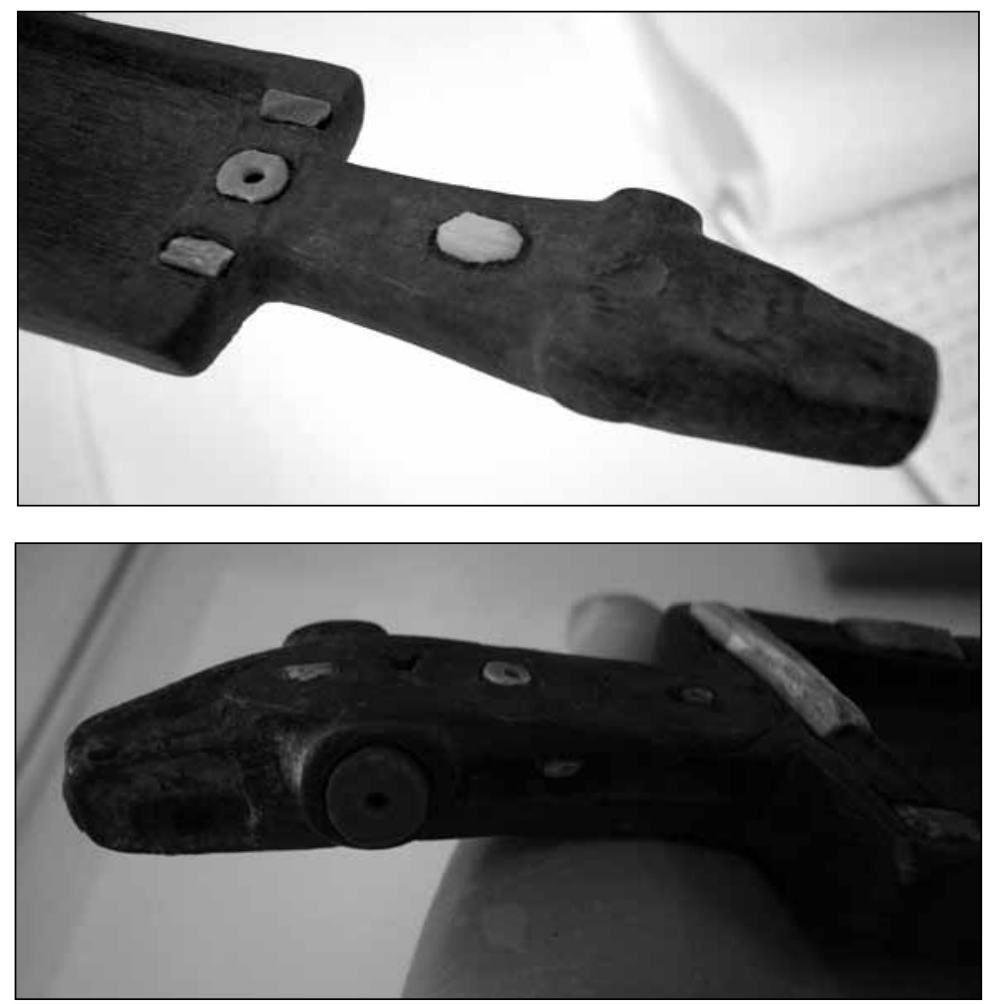

Figura 2 a y b. Tabletas prehispánicas con figura de felino y apariencia de reptil (Instituto de Investigaciones Arqueológicas y Museo R.P. Gustavo Le Paige, tumbas 1560 y 1417 de Yaye-1; fotografías de Helena Horta).

campesinos de Lasana del siglo XVII. En el hueco de las tabletas depositaban los primeros granos que cogían de sus sementeras y los ofrecían en adoración. Si la tableta se había convertido en un ídolo, o en una representación de una divinidad a la que se ofrecía adoración o se agradecía por los frutos cosechados, estamos ante una resemantización colonial, donde un objeto antiguo y sagrado conectaba también con un pasado cuya memoria se desvanecía. La figura representada, a juicio de Horta, remitiría más bien a un felino, mal interpretado por los extirpadores que confundieron la cola del felino estilizado con la de un mono (ver Figuras ra y b).

La segunda tableta o ídolo, correspondiente a Caspana, es descrita en el documento como una figura "a manera de lagarto de la mesma madera con la voca avierta al qual le ofresian piedras de varios colores de pedernales y polvos de colores y davanle adorassion en Vn alto serro que mira al de Potosí". Esta tableta ha sido identificada por Helena Horta como de estilo circumpuneño, con la representación de una cabeza de felino, no obstante su apariencia de reptil (Figura 2a y b). Algunas de ellas tienen incrustaciones de piedras semipreciosas y por ello no parece extraño que le ofrecieran piedras y polvos de colores, quizá una reminiscencia de las antiguas ofrendas de alimentos a la huacas. Sin embargo resulta también notable que lo hicieran en lo alto de un cerro que miraba a Potosí. ¿Por qué a Potosí? El mineral "descubierto" en 1545 reorganizó toda la economía regional, convirtiéndose en un nuevo centro articulador del espacio económico (Assadourian 1972, 1979; Bakewell 1984: 3-4). Estos autores, siguiendo a Capoche [1585] nos dejan la impresión de que Potosí estaba deshabitado y no era un lugar importante ni central en tiempos prehispánicos. En esta perspectiva la mirada al cerro de Potosí como a un "ceque" (Zuidema 1995), es decir como integrando una línea imaginaria que vinculaba lugares sagrados a los que un grupo de parentesco rendía culto, estaría datando este rito como de recreación indígena colonial. Sin embargo, investigaciones recientes indican que Potosí era una huaca incaica de gran prestigio 
y que su despoblamiento, de acuerdo a las evidencias arqueológicas, era solo un mito. Por lo tanto cabe la fuerte posibilidad de que la adoración en aquel cerro sagrado de Atacama que miraba a la huaca de Potosí se haya tratado de una tradición con raíces prehispánicas (BouysseCassagne 2008; Cruz y Absi 2008; Platt y Quisbert 2008; Platt et al. 2006; Salazar-Soler 1997; Téreygeol y Castro 2008; Gisbert 2010). De modo que nos encontramos ante una situación compleja. Sin embargo la resemantización colonial de la tableta alucinógena, para un uso ritual distinto, es una indicación de cómo estaban cambiando los cultos, las memorias y la renovación de la religiosidad andina.

Respecto al tercer ídolo encontrado en el pueblo de Ayquina, el documento señala:

"...saco el tercero ydolo de en medio de un caudaloso rrio que estava colocado en Vna peña que estava en la mitad de el y la bañavan las aguas por entrambos lados a este ydolo segun dixeron los casiques le rendian adorassion y culto llevando el principal governador en las manos Vna olla nueba y otras veses cargandola en las espaldas y llena de mais yba la yndia mas ansiana con vn palito sutil y delgado tocandole y en llegando que llegavan con esta seremonia al rrio quebravan la olla en la dicha peña y levantando el grito a voses desian Caiatunar, que en su lengua materna dissen lo que en nuestro idioma Hispanico buena cosecha" (AGI, Lima 263, 9, 1677, fs. 9v, 10v).

Este ídolo está estrechamente vinculado con la ansiedad por el agua y buenos resultados en la cosecha. Parece, además, tener claras vinculaciones con las ceremonias contemporáneas de limpia de canales, tema que escapa a este artículo (ver, entre otros autores, Barthel 1986 [1957]; Castro y Varela 1994; Castro y Aldunate 2003). En Ayquina, un rito comunitario de fertilidad era encabezado por el gobernador indígena -probablemente el cacique principal, es decir la más alta investidura de su sector- quien dependía de las autoridades hispanas y debía colaborar con la evangelización. Sin embargo, a la vez, necesitaba legitimarse ante su pueblo encabezando antiguos ritos de fertilidad y otros cultos como a los antepasados y a las huacas (ver Millones 1979; Salomon 1990). Los caciques fueron los sujetos a los que se prestaba atención preferente por parte de los evangelizadores, pues se pensaba que ellos podían influenciar e inclinar a los indios del común a acoger la doctrina cristiana y co- laborar con ella..$^{30}$ De modo que este rito también expresa las creaciones indígenas frente a las contradicciones de la vida colonial. Hay varios elementos rituales que se asemejan a los contemporáneos, como el sacrificio del cántaro, que hoy se llama Santo Waki, ${ }^{31}$ cuyo contenido de vino consagrado por una larga ceremonia, es ofrecido por el purikamani $i^{32}$ al soltar las primeras aguas de la acequia después de la limpia del canal en tributo de la Pachamama y los cerros tutelares a los que también se ofrecen otros objetos, entre ellos coca, ulpo, chicha, para pedir "buenas siembras y buenas cosechas" (Castro et al. 1994: 586o). La ceremonia, que implica un duro y festivo trabajo comunitario que se prolonga por varios días, está acompañada de abundantes comidas y bebidas, bailes y una liturgia cristiana en la iglesia del pueblo. El Santo Waki o cántaro nuevo, cuyo contenido se va a ofrecer, en Ayquina se deja la noche anterior en la cocha o sector de acumulación del agua para el regadío, en una "mesa" o una peña escalonada que "representa al Mallku Panire el principal cerro tutelar de la comunidad" (Castro et al. 1994: 4656). En cambio en Toconce se deja enterrado "el jueves de Víspera detrás de la iglesia", días antes, en una ceremonia privada, el purikamani ha vertido "uno de los cántaros en la 'mesa' ritual que se encuentra detrás de la iglesia y al lado del canal en Toconce" (Castro et al. 1994: 29, 66).

\footnotetext{
${ }^{30}$ De allí que una parte del esfuerzo de extirpación de idolatrías se dirigió a la creación de colegios de hijos de caciques.

${ }^{31}$ Castro et al. (1994: 107) definen waki de la siguiente manera: "En uno de sus significados más amplios es el rito en el cual se ofrenda ("pago") y agradece a las divinidades, a las "almas" y a las "antigüedades" ("abuelos", "ante abuelos" y rey Inka). En este sentido, el waki comprende necesariamente la existencia de alcohol, vino o tinka, hojas de coca, y el acto de asperjar estos ingredientes sobre la Pachamama o el agua de los canales o kocha. Esta ceremonia se efectúa principalmente cuando se va a llevar a cabo un acto importante o sagrado a nivel comunal o familiar. Los cántaros u otros contenedores de la ofrenda también reciben el nombre de waki. En lengua aymara, waki significa parte, porción, precio. Este acto sagrado está siempre presente en las ceremonias del ciclo calendárico, pero en el transcurrir cotidiano del grupo familiar, pueden existir muchas razones para realizar un waki, de modo que el concepto es muchísimo más complejo".

32 Castro et al. (1994: 104) definen al purikamani como "el cargo de mayor especialización y jerarquía dentro de la limpia de canales. En quechua, purini es andar, caminar, correr lo líquido y camani, dar parte. En aymara, pura significa nosotros y camani el más digno. Ambas lenguas dan sentido al significado de este cargo". La definición se extiende en la electividad, duración y responsabilidad del cargo.
} 
Llama la atención que en el actual Toconce, como en San Pedro de Atacama en el siglo XVII, el espacio posterior de ambas iglesias se usara para fines rituales de raíz andina.

La voz "caiatunar" que es traducida por buena cosecha, tiene respaldo en el "Glosario de la Lengua Atacameña" que reunió cerca de 1100 voces recopiladas por Emilio Vaïsse, Félix Hoyos y Aníbal Echeverría y Reyes, publicada en 1896. Ckaya es traducida por bien y bueno (Vaïsse et al. 2006 [1896]: 18); Ttunar a su vez por "terreno (Sepetunar: terreno de Peine donde siembran maíz azul.)"; "Ttupia: coronta"; "Ttuti: mazorca" (Vaïsse et al. 2006 [1896]: 33). El significado de buena cosecha que nos provee este documento, entonces, aporta con una nueva expresión en kunza y apunta a una acepción no incluida por los investigadores de fines del siglo XIX y es que Ttunar signifique también cosecha, aunque podría estar más directamente asociada a la idea de cosecha de maíz.

\section{* Énfasis finales}

La secuencia descrita en este trabajo, indica que en Atacama el proceso de extirpación y re-evangelización fue largo e intenso y nos muestra que los procesos de resemantización de algunos objetos de culto tradicionales, como las "tabletas para usos alucinógenos" descritas, se habían iniciado con anterioridad a la intervención religiosa de los extirpadores, lo que indica a su vez los procesos creativos de los campesinos indígenas, así como las profundas transformaciones ocurridas en las costumbres y tradiciones andinas. Se puede señalar, entonces, que a mediados del siglo XVII se descubrieron ritos de fertilidad locales, lugares sagrados asociados a los mismos, vinculaciones de autoridades políticas indígenas, como también ciertas reminiscencias de ceques ${ }^{33}$ y cultos a las montañas, junto a cultos a dioses mayores que eran compartidos con otros grupos étnicos. Estas tradiciones fueron en parte eliminadas o transformadas, por los indígenas y los extirpadores, en la creación dialéctica del cristianismo atacameño.

Es llamativo que la campaña extirpadora de Otal hubiese permitido la formación de una red de extirpadores

33 Respecto a ceques puede verse el clásico trabajo de Zuidema (1995) para el Cusco, la síntesis de Wachtel (1973) y a nivel regional, los textos de Barthel (1986) y de Castro (2009). que le acompañaría o le sucederían con los años en la misma provincia. Se trata de una red que no solo está conectada en las actividades pastorales, también tendieron a reforzar mutuamente sus carreras eclesiásticas y donde el éxito económico de Otal jugó un papel importante, que le permitió ser el personaje central del proceso.

Los procesos por idolatrías abren también la posibilidad de analizar las lecturas cruzadas que se dieron en las apropiaciones indígenas del cristianismo. La tendencia fue, como se sostiene en el texto, a un reforzamiento, aunque unidireccional, de la eficacia simbólica atribuida a los objetos y lenguajes prehispánicos, a partir de su relación con estructuras pastorales (como es el caso de las iglesias). A la larga, y aunque no hubiesen mediado campañas de extirpación de idolatrías, este reforzamiento unidireccional, alentó una transformación de la "idolatría colonial”, tal como lo ha señalado Gruzinski (1991), respecto de Nueva España.

El análisis de los cultos locales, básicamente destinados a asegurar la abundancia, la reproducción social, la fertilidad de los cultivos, en los que "huaca" e "iglesia" comparten los mismos atributos simbólicos, podría vincularse a estrategias de reinterpretación y negociación simbólica construidas en las últimas décadas del siglo XVI. Francisco de Otal viene a romper esa estructura, muy probablemente por el hecho de que su acción fue valorada positivamente por los atacamas, en el sentido de que transformó el espacio productivo, y de que no solo fue el cura doctrinero, sino también un agente gracias al cual aumentó la producción de bienes. Es decir se convirtió en un aviador o un proveedor. ¿No habrían interpretado los propios indígenas que aquello se debía a la vinculación que mantenía el doctrinero con la Iglesia? Pensamos que dos documentos de mediados del siglo XVIII contribuyen a apoyar esta última hipótesis.

Uno de ellos es una carta del gobernador de Toconao, junto a otros caciques, dirigida al gobernador de Atacama Pascual Sebastián Guacasur ${ }^{34}$ en la que denunciaban los abusos de curas y corregidores. Del cura Don Bernardo Ochova, se quejaban por tener al pueblo alborotado,

\footnotetext{
${ }^{34}$ En la referencia o ficha de este documento en el ABNB, se lee "Guacasus", pero en el texto manuscrito leemos "Guacasur".
} 
acusándolos de alzados. Se quejaban porque no se habían podido confesar puesto que su gente no sabía otra lengua, acusación que implicaba que su cura tampoco la conocía. Además, habían tolerado "tantas de su ermano don Bernardo de Ochova mujeres casadas y solteras". Por otra parte, señalaban que el cura de Chiu Chiu y el corregidor les habían levantado falsos testimonios.

En consecuencia, Don Pascual Sebastián Guacasur, quien se identificaba como gobernador y cacique principal de los indios del anejo de Belén de Susques (Puna de Atacama), dependiente del pueblo de Toconao de Atacama la Alta, en nombre de toda su comunidad, solicitó al Fiscal Protector General de la Real Audiencia de La Plata, ser protegido del corregidor Manuel de Valdivieso, quien lo quería hacer pagar injustamente 40 pesos por cada 14 indios -que señalaba no conocer- y que aquél había incluido en la última visita, en circunstancias que tenía el pago de tributos al día y que el corregidor no había hecho la visita anual.

Agregaba que habitaba en el anexo de Susques, junto al resto de los indios, ubicado a una distancia de más de 50 leguas de Toconao

"Y por esa rason no puede venir el cura del dicho Pueblo a este anejo a darnos el pasto espiritual y estamos caresiendo de oyr misas y de confesarnos aviendo Capilla consagrada en el dicho anejo donde suele aver misa y ayudante para confesarnos y en estos dos años no emos oydo misa ni confesadonos por no haber sacerdote en grave daño y perjuicio de nuestras almas [...] represento a su Altesa para que ponga el debido remedio [...] sin permitir muramos sin oir misas y in confesarnos como todos aquellos miserables Yndios e Yndias que murieron en estos dichos dos años pasados sin confesarse ni oir misas y el sacerdote que fuere Señor, a de ser que entienda nuestra lengua para confesarnos y en aquellos lugares no hay Señor Sacerdote que entienda nuestra lengua mas que tan solamente el licenciado Don Bernardo Zoleita Clérigo Presvitero quien asiste en el dicho Pueblo de Atacama a quien se le puede mandar a que baia al dicho anejo a darnos el pasto espiritual a quien protestamos de darle casa y servirle por este bien que nos hisiere y desde tan lejanas tierras e venido Señor gastando lo que Dios sabe y dejando mi casa mujer e hijos desamparados a fin de alcanzar de la poderosa mano de su Altesa el que tengamos sacerdote en el dicho anejo..." (ABNB, E 1757, 50).35

\footnotetext{
35 El Fiscal Protector General, a quien estaba dirigida la solicitud, recomendó a la Real Audiencia de La Plata acoger las dos solicitu-
}

Para nuestro propósito es importante destacar de este documento, por una parte, la profundidad de las creencias cristianas entre la comunidad de los indios de un pueblo tan apartado como Susques en 1757, a pesar de los malos ejemplos de algunos religiosos; y por otra, la capacidad política de negociación de las comunidades representadas por sus caciques para hacerse escuchar en las más altas esferas judiciales y políticas a las que tenían acceso, a pesar de los enemigos internos. Los reclamos no eran contra las autoridades civiles y eclesiásticas, sino contra sus abusos, de acuerdo a las normas del sistema colonial, a cuya lógica acudían para defender sus derechos. Su condición de miserables y desvalidos los hacía dignos de protección y justicia real, así como el riesgo de sus almas debía ser una atención preferente de los eclesiásticos, especialmente en el momento de la muerte.

El segundo documento es muy significativo en lo que se refiere al cambio de la mentalidad religiosa de la población originaria de Atacama. Se trata de un escrito encontrado por Priscilla Cisternas en el Archivo y Biblioteca Arquidiocesano Monseñor Taborga (ABAS), Sección Arzobispal, Sucre, quien nos ha facilitado su transcripción. El tema central del documento es que por encontrarse excomulgado el cura de Atacama Don Bernabé Zuleta, ${ }^{32}$ por motivos que no se señalan, se habían producido nefastas consecuencias en el clima, las cosechas y fertilidad de los productos agrícolas de esa localidad, por lo que solicitaban que se le levantara la excomunión o bien que fuera reemplazado alejándolo del pueblo (ABAS, Sección Arzobispal, 130, 1756). Las relaciones que establecen los indígenas, entre la excomunión del cura doctrinero y las consecuencias que se señalan en esta carta, no son arbitrarias, y resultan ser indicativas de la circulación de contenidos pastorales, como es el caso de las consecuencias que atraía la excomunión, y su asociación con acontecimientos adversos para el pueblo de San Pedro de Atacama. Aunque los concilios y sínodos habían establecido que a los indígenas no les era aplicable la excomunión, ni ningún tipo de censura eclesiástica, habida cuenta de su "incapacidad". Sin embargo, nada impide observar que tenían una clara comprensión de sus implicancias.

des del cacique de Toconao.

${ }^{36}$ Sin duda se trata del mismo sacerdote mencionado en el documento anterior como Bernardo Zoleita. 
En el momento en que se observaban "nefastas consecuencias", el cura Bernabé Zuleta bien podía ser considerado como un "excomulgado no tolerado", por cuanto su nombre o su oficio habían sido puestos en una tablilla en la iglesia del pueblo, a diferencia de un "excomulgado tolerado" que no se encontraba identificado por nombre ni por oficio. La excomunión correspondía a una censura o pena eclesiástica que privaba "de algunos bienes externos y públicos, quales son los Sacramentos, Sacrificios, Beneficios Eclesiásticos, Jurisdiccion espiritual, públicos sufragios, y satisfacciones, y otras cosas semejantes" (Larraga 1780: 275). En tanto "excomulgado no tolerado", el cura Zuleta se encontraba privado de jurisdicción y sus actos debían ser considerados nulos, con excepción de la absolución que hiciese "al penitente que está in articulo mortis". ${ }^{77}$ Además, de haber sido objeto de excomunión mayor, estaba privado de toda comunicación política y sagrada con los fieles..$^{8}$ Esto imposibilitaba la reproducción de una eficacia simbólica cuya manipulación dependía del lenguaje ritual dominado por el cura doctrinero.

En parte ambos documentos pudieron generarse en una disputa de los dos curas, con sus respectivos aliados indígenas para prevalecer en la doctrina o, en el caso de Bernabé Zuleta, lograr un traslado a Susques y que se le levantara la excomunión. Por otra parte también corresponde al gobierno en el corregimiento de Manuel Fernández Valdivieso, personaje que después de diversos abusos fue acusado ante la Real Audiencia de La Plata por los propios indígenas, episodio que envolvió a toda la comunidad y a los sacerdotes (Hidalgo 1982, 2004; Hidalgo y Castro 1988, 1999; Castro e Hidalgo 1999; Castro et al. 2002). No obstante las consideraciones anteriores, las cartas de los indígenas son genuinas y escritas en el lenguaje de los campesinos, más que si hubiesen sido escritas o dictadas por los religiosos. De modo que dejando presente esta cautela, en nuestra perspectiva, ambos documentos reflejan las transformaciones de las mentalidades religiosas andinas.

\footnotetext{
37 Larraga 1780: 285. Ver también Pacheco (1760). Agradezco estas referencias a Nelson Castro.

${ }^{38}$ Para mayores antecedentes sobre las censuras eclesiásticas, consúltese Larraga (1780) y Pacheco (1760). Para un análisis de los usos y repercusiones que tuvo el recurso a las censuras eclesiásticas en el virreinato peruano, consúltese Castro e Hidalgo (2008).
}

Por otra parte hay disposiciones del arzobispo de Lima Antonio Soloaga, en 1715, para hacer rogativas por buenas cosechas con motivo de la esterilidad de los campos. El mismo año dictó un edicto exhortando a los feligreses a la devoción de San Isidro Labrador. No sabemos si estas influencias llegaron a otros obispados, pero considerando que se trata de tradiciones españolas que compartían las distintas autoridades religiosas en América es muy probable que así haya sido (AGI Lima 520).

Estamos entonces ante una manifestación específica e inesperada del catolicismo andino. Contrariamente a la tesis de Abercombrie $(1986,1991)$, que plantea una doble articulación, en el sentido de que la Iglesia cristiana permitiría al grupo étnico k'ulta una vinculación con la sociedad nacional, pero que el exceso de permanencia en ella -como el tiempo de duración de su techado- produciría infertilidad. La fertilidad y la reproducción de la sociedad, en cambio, se lograría mediante las costumbres o ritos tradicionales andinos. En Atacama, sin embargo, nos encontramos con que es el cura excomulgado la fuente de la ruina del pueblo. Es decir la fertilidad se asocia a los ritos católicos y a la persona del cura. En efecto, la fertilidad parece haber sido el principal don de las huacas coloniales, pero el proceso de extirpación encabezado por Otal habría logrado que la disputa por la negociación simbólica permitiera transferir algunos de los atributos de esos dioses a los curas coloniales. Esto no invalidó que los atacamas siguieran practicando sus ritos o costumbres, como la limpia de canales, que se asocian al culto a los cerros y a la Pachamama, junto a oraciones cristianas para solicitar la abundancia de agua que asegurara buenas cosechas.

En síntesis, en consideración a los antecedentes expuestos, proponemos tres etapas en la relación de los atacamas con el lenguaje ritual expandido por los procesos de evangelización. Una etapa previa a Francisco de Otal, que va desde fines del siglo XVI a las primeras cuatro décadas del siglo XVII, donde la Iglesia y las huacas comparten los mismos valores simbólicos, teniendo estas últimas mayor importancia en los ritos de fertilidad. Una segunda etapa, de extirpación y evangelización intensiva del cristianismo emprendida por las redes eclesiásticas que hemos analizado y donde Otal aparece como el proveedor y otorgador de prosperidad para los atacameños, la que se extiende aproximadamente desde 1635 hasta cerca de 


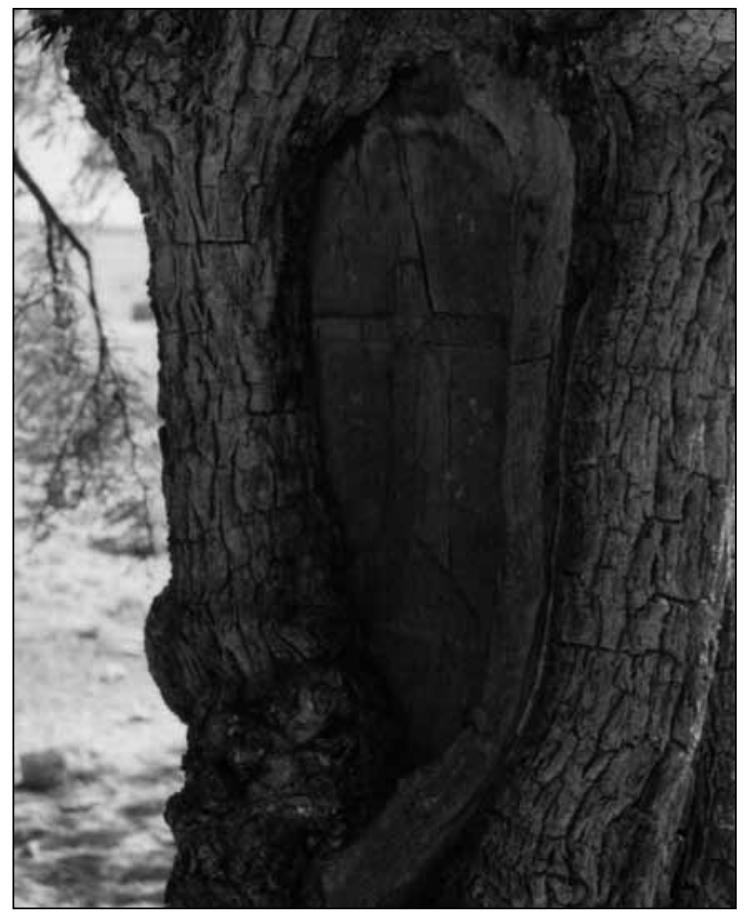

Figura 3 a y b. Tamarugo del oasis de Tilomonte, posible testimonio de los procesos de extirpación de idolatrías. Presenta el tallado de una cruz y las leyendas: "Año 1681" y "V I Concebida”, es decir Virgen Inmaculada Concebida. Posiblemente se trató de un árbol sagrado o huaca, que fue cristianizado y santificado (fotografía de Francisco Gedda).

1650 y que se renueva con el accionar de otros sacerdotes hasta fines del siglo XVII. Finalmente, una apropiación de las principales enseñanzas del cristianismo colonial, pero donde algunos de los atributos de las huacas han sido traspasados simbólicamente al Dios cristiano, a la Iglesia y a sus representantes. ¿Quiere decir esto que los atacamas habrían abandonado otras tradiciones religiosas? No parece ser el caso. Prácticas cúlticas como el consumo de alucinógenos (que pudieron ser reemplazados por el consumo de bebidas alcohólicas) divinidades prehispánicas y coloniales, desaparecen, sobreviven o son recreadas, sin que ello constituya una contradicción ni dé origen a nuevas persecuciones eclesiásticas. La sociedad colonial, en términos religiosos, parece haber alcanzado un consenso relativo que le permite convivir en un mundo donde los imaginarios se han integrado creativamente (Figura 3). Sin embargo siguen existiendo esferas que se mantienen como propias de la actividad eclesiástica y otras propias de los cultos campesinos. Si bien las comunidades en ambas otorgan a las prácticas rituales de los sacerdotes cristianos una eficacia simbólica que segura- mente habría sido rechazada por aquellos extirpadores de idolatrías, escépticos a este tipo de creencias, pero temerosos, a su vez, de la posible influencia demoníaca.

Agradecimientos Agradezco otros aportes documentales que me facilitaron los colegas Nelson Castro y Priscilla Cisterna. A Helena Horta por sus observaciones, interpretaciones e imágenes de tabletas alucinógenas. A María Marsilli por sus comentarios al manuscrito. A Francisco Gedda por sus fotografías. Agradezco también a los colegas que en Sucre me hicieron valiosas sugerencias, entre ellos a Tristan Platt, Pablo Quisbert, Viviana Manríquez, José Luis Martínez, Cecilia Sanhueza, Pablo Cruz, entre otros, y muy especialmente a los integrantes del Proyecto FONDECYT 1100132 Nelson Castro, Priscilla Cisternas y Julio Aguilar, que han hecho distintos aportes, desde documentales a sugerencias de contenido. A Azun Candina, colega del Departamento de Ciencias Históricas de la Universidad de Chile por la traducción del Resumen. No obstante, los defectos de este trabajo son de mi exclusiva responsabilidad. 


\section{$*$ ANEXO $_{1}$}

ABNB, EC 1650, núm. 17. Información de los servicios del licenciado Francisco de Otal, racionero de la Catedral de La Plata. ${ }^{39}$

Transcripción de Priscilla Cisternas. ${ }^{40}$

[f. $1 \mathrm{r}]$

En la ciudad de la plata provincia de los Charcas del piru en onze días del mes de Octubre de mil i seisçientos y cinquenta años el señor Dotor Don Luis Joseph merlo de la fuente del conssexo de su magestad su Oydor y alcalde de corte en esta real audiencia mando pareçer ante si al Padre Benito bravo de la compañía de Jesus sacerdote del qual se le reçevio juramento por Dios nuestro señor y una señal de cruz poniendo la mano en el dicho prometió de desir verdad y siendo preguntado por el tenor del pedimiento dixo lo siguiente

Que a seis años que conoçio al liçenciado don francisco de otal raçionero de la santa iglesia desta ciudad en la provinçia de atacama alta y baxa y en el puerto de cobija donde anduvo ocupado este declarante en una misión de las que acostumbra la compañía predicando y confesando a todos los mas de aquella provincia y hallo al dicho Licenciado francisco de otal en este tiempo exerçiendo el ofiçio de cura en atacama la baxa y el de vicario comissario de la santa cruzada y santo ofiçio y vissitador y Juez de la Ydolatria asi en esta provinçia como en la de atacama la alta. $\mathrm{Y}$ assimesmo sabe este declarante que todo lo que se refiere en la petision y recaudos que tiene presentados el dicho raçionero assi de puestos y ocupaciones

\section{[f. IV]}

que ha tenido en la dicha provincia como el cuidado y vigilancia con que acudio a ellas es cierto y verdadero y en lo tocante a la vissita de la ydolatria anduvo por los mesmos pueblos donde se hiçieron las diligençias y trato y vio a los mesmos yndios y a muchos de ellos penitençiados por el dicho raçionero y sabe que fue yndezible el travaxo que tuvo en este particular por la grande distancia de los pueblos y lugares de malos caminos y de poblados faltos de todo lo necessario para la vida humana llevando consigo para el buen efecto desto mucha gente que le ayudo sustentandola a su costa todo el tiempo que duro la vissita y esperimento que fue de grande servicio a nuestro señor El cuidado y trabaxo que el dicho raçionero tubo en la dicha vissita con lo qual dize este declarante que no fue tan grande el travaxo que tuvo en la mission que yba haziendo por la buena disposission con que hallava a los yndios y siendo assi que semexantes visitas suelen engendrar odio y rencor en los visitados tubo tan buen modo el dicho raçionero y se supo dar tal

\footnotetext{
39 Documento ubicado en el ABNB, por Nelson Castro, co-investigador del Proyecto FONDECYT 1100132.

${ }^{40}$ Asistente en el Proyecto FONDECYT 1100132.
}

maña que sin faltar al buen efecto de su visita. Y extirpando tantas ydolatrias como antes avia estavan los dichos yndios tan agradeçidos y reconoçidos a el bien que les avia hecho que quedo muy admirado y assimesmo save que hizo el dicho raçionero quemar mas de veynte ydolos que los yndios adoravan de varias materias y nombres en la plaça grande del pueblo de atacama la alta llevando el mesmo raçionero en sus ombros la leña con que se quemaron

y en quanto al modo de proçeder del dicho Raçionero dixo que quando llego a su beneficio hallo muy buen nombre del asi en lo tocante a su perssona como en lo tocante a los dichos

\section{[f. 2 r]}

ofiçios que exerçia habiendose también en los yndios que no avia quexa alguna de el por ser muy desinteresado y socorrerlos en todas sus neçessidades sin llevarle nada por bautismos entierros casamientos ni belaçiones y otras cosas tocantes a el dicho ministerio y tan çeloso del bien de sus obexas que no se contentava con acudir el personalmente a la dotrina dellas sino que también tenia otro saçerdote que le ayudava quien le dava estipendio de su bolsa

preguntado por el señor oydor si el dicho raçionero o sus mayores an de servido en algo a su magestad dixo que dize lo que dicho tiene en rason de los buenos procedimientos del dicho racionero y que en quanto a sus mayores no sabe ni a entendido que nunca ay de sservido a su magestad sino acudido como leall vassallo ssuyopreguntado si el dicho raçionero a sido remunerado por los dichos serviçios dixo que no save que por dichos serviçios aya tenido mas remuneraçion que la raçion que al presente tiene y esto responde

preguntado que le pareçe a este testigo que por dichos serviçios merecera el dicho racionero dixo que por rrason de dichos serviçios merecera muy dignamente vna dignidad en esta santa iglesia donde podrá acabar su vida siendo su magestad servido y esta es la verdad en que se afirmo y ratifico dixo ser de edad de quarenta años no le tocan las generales y lo firmo con el dicho señor oydor lo señalo

Benito Bravos [rubricado]

Ante mi

Don Joseph Giron [rubricado]

\section{[f. 2v]}

En el dicho dia mes y año dicho el dicho oydor para la dicha ynfomaçion mando pareçer ante si al Padre fray Juan Bautista guardian del combento de recoleçion de nuestro Padre San francisco desta ciudad del qual se recivió juramento por dios nuestro señor y una señal de la cruz e ymberbo sacerdotis y puesta lo mano en el pecho y prometió de desir la verdad y siendo preguntado por el tenor del dicho memorial dixo que conoçe al dicho raçionero francisco de otal de mas de treinta años a esta parte 
y siempre con muchas noticias de su loable vida y buenas costumbres y zeloso de la honrra y gloria de nuestro señor siendo de los primeros en todo y el que con su zelo siendo cura y vicario de las provinçias de atacama y comisario del santo ofiçio y cruzada reformo muchas supersticiones y adoraciones falsas de ydolatria y entre otras de amonestaçiones que hizo condeno dos de los ydolatras mas prinçipales al serviçio desta santa recoleçion donde vivieron mas de dies años y el dicho racionero llevado de su virtud y christiandad a hecho de veynte y quatro años a esta parte limosna de tres cargas de pescado en cada uno fuera de otras buenas obras que a hecho por lo qual a sido y es estimada su perssona de los prelados y superiores haciendo del dicho racionero mucha estimacion en todas las ocasiones que se an ofrecido y en orden a todos los demás ofiçios y puestos que a exercido y son notorios se remite a los recados y testimonios que dello tiene y save que a gastado su hasienda

\section{[f. $3 \mathrm{r}$ ]}

en estos ministerios por dar buena quenta como buen eclesiastico y esto Responde

Preguntado por el señor oydor si save este testigo que el dicho raçionero o sus mayores ayan de sservido a su magestad dixo que no le consta de tal sino de lo contrario haviendo el dicho Raçionero por mas servir a su magestad gastado su haçienda en estas ocupaciones y que en quanto a sus mayores no save ni a entendido cossa en contrario y esto responde

Preguntado si save que por rason de dichos serviçios aya sido remunerado el dicho racionero dixo que no save aya tenido mas premio que la dicha raçion en que al presente esta

Preguntado en que le pareçe a este declarante que podra ser remunerado el dicho racionero dixo que es muy digno de qual quiera dignidad de esta santa iglessia en que pueda acabar los días de su vida por estar por mas servirle ympedido de una pierna que se le quebro y en esto le pareçe que siendo su magestad servido le podra acomodar y esto dixo ser la verdad so cargo del dicho juramento en que se afirmo y ratifico siéndole leydo y que es de edad de setenta años poco mas o menos y que no le tocan las generales y lo firmo y señalo el dicho señor oydor

\section{Fray Juan Baptista [rubricado]}

\section{Ante $\mathrm{mi}$}

Don Joseph Giron [rubricado]

\section{[f. 3v]}

En dicho dia mes y año el dicho señor oidor para la dicha información mando parecer ante si a Don pablo Rodriguez de la cruz del qual se resibio juramento a Dios nuestro señor y una señal de la cruz y en forma de derecho: so cargo del qual se prometio desir verdad en lo que se le preguntare =

Y siendo preguntado por el tenor del dicho memorial, Dixo que conoce al Raçionero francisco de otal de mas de beinte años a esta parte el qual ha procedido con conosida virtud buen exemplo y abentaxado celo del poblándose los pueblos de los yndios por seguir su dotrina aclamándole por uno de los primeros y mas exemplares curas de los yndios el qual mediante su zelo y virtud a costa de su hasienda y vida arresgandola muchas veses hasta quebrarsele una pierna, quito muchos abusos de supersticiones de idolatría y adoraciones falsas castigando a los infieles y predicándoles con tanto celo que los reduçira a que viniessen en conosimiento del verdadero Dios por lo qual ha sido y es de los prelados y superiores honrado

\section{[f. $4 \mathrm{r}$ ]}

y estimado y conosiendo sus partes de virtud y letras se han ocupado en los puestos que refiere el dicho memorial que son notorios y se remite a los recados que tiene dellos y esto responde $=$

preguntado si sabe que el dicho raçionero o sus maiores aian algo de servido a su magestad dixo que no tiene notiçia de tal sino antes de lo contrario y esto responde =

preguntado si sabe que por raçon de dichos servicios aia sido remunerado dellos el dicho racionero =

Dixo que no sabe que aia tenido mas remuneraçion que la raçion en que al presente esta $=$

Preguntado en que le parece a este declarante podrá ser remunerado el dicho racionero $=$

Dixo que atento a sus años y achaques y estar impedido y quebrada una pierna en serviçio de su magestad siente se le deve haser merced de una dignidad o calongia [sic] desta santa iglesia en que pueda acabar su vida y que siendo su magestad servido le puede

[f. 4v]

haser la dicha merced y que lo que dicho tiene es la verdad so cargo del juramento fecho y que es de hedad de quarenta años y lo firmo y el dicho señor oidor lo señalo

don Pablo Rodriguez de la cruz [rubricado]

ante $\mathrm{mi}$

Don Joseph Giron [rubricado]

En dicho dia ante el dicho Señor oidor para la dicha informacion el padre Letor fray rodrigo mançano jura a Dios nuestro señor in verbo saçerdotis puesta la mano en el pecho so cargo del qual dicho juramento prometió desir verdad $=$

Y siendo preguntado al tenor de dicho memorial

Dixo que conose al dicho racionero de sinco o seis años a esta parte y le ha visto proseder con toda virtud ajustamiento y buen exemplo dando abentaxada cuenta de lo que ha estado a su cargo y sabe que ha mas de beinte años que ha sido cura y vicario de atacama y comisario del santo ofiçio y cruçada y mediante su çelo a cos

f. 5 r.

[al margen: sello 30 años digo =]

A costa de su hasienda y vida quito muchos abusos y supres- 
ticiones de ydolos falsos que adoraban los yndios a quienes enseñaba la berdadera doctrina obrando mucho el exemplar proçeder del dicho rrasionero mediante lo qual no ha visto este declarante gente mas vien dotrinada ni que mas vien acuda al culto dibino que la de aquellas provinçias de que consta a este declarante como testigo de vista sin que tratasse demás intereses que serbir tantos años de valde el dciho beneficio sin llebar obençiones ningunos por raçon de bautismos cassamientos ni entierro: y assi a sido mui estimada y aplaudida su persona $y$ honrrada de los prelados y superiores y esto rresponde =

Preguntado si sabe que el dicho rasionero a sus mayores ayan de serbido en algo a su magestad = dixo que no sabe ni a entendido cossa en contrario de lo que tiene dicho sino que antes por mas serbir a su magestad, a Padeçido muchos trabajos hasta quebrarsele vna pierna $=$

Preguntado si sabe que el dicho rrasionero por razon de dichos serbiçios aya tenido alguna rremuneraçion dixo que no sabe aya obtenido

\section{[f. $5 \mathrm{v}$ ]}

\section{mas que la rraçion que oy posee}

Preguntado en que le parese a este declarante podra ser remunerado el dicho rrasionero = dixo que atento a sus años y impedimento de la pierna siente que es digno de que su magestad le honrre en vna de las dignidades desta santa yglesia de la plata y que esto es la verdad so cargo del juramento que fecho tiene $y$ que es de hedad de quarenta y quatro años no le tocan las generales de la ley y lo firmo y el dicho señor oydor lo señalo

\section{Fray Rodrigo Mançano [rubricado]}

Ante mi

Don Joseph Giron [rubricado]

En la ciudad de la plata en diez y nuebe de octubre, para la informacion de suso referida el dicho señor oidor mando pareser ante si a don miguel de chalas secretario y contador del venerable y muy insigne dean y cavildo desta santa yglesia de los charcas y recetor[?] del santo tribunal de la inquisiçion destos reinos y en todo el distrito desta dicha ciudad del qual se resi

\section{[f. 6r]}

[al margen: sello 30 años digo]

bio juramento por Dios nuestro señor y una señal de la cruz en forma de derecho so cargo del qual prometió dezir verdad y siendo preguntado por el tenor del dicho memorial =

Dixo que este testigo ha quinse años poco mas o menos que entro en esta ciudad y provinçia en servicio del muy reverendo Señor maestro Doctor frai francisco de borxa de buena memoria arçobispo que fue de la dicha santa yglesia a quien este testigo sirvió de secretario de cámara todo el tiempo de su arçobispado hasta que fallesio y ha catorse años poco mas o menos que conose por cartas de vista trato y comunicasion al Licenciado francisco otal raçionero desta dicha santa yglesia y como tal secretario que fue del dicho mui reverendo arçobispo sabe por averlo visto que teniendo larga noticias y relaciones su Señoria Ilustrisima de personas de toda autoridad satisfaçion y crédito de la ajustada vida y costumbres del dicho racionero siendo cura de atacama y que aquella provinçia estaba infestada de chicos y grandes de sus antiguos ritos y idolatría y estando enterado de su mucha christiandad y çelo de la causa de maior serviçio de Dios nuestro señor queriendo ir en persona el dicho arçobispo a la extirpasion de dichas idolatrías y a procurar reducir con firmesa a los dichos indios atacamas al verdadero conosimiento de nuestra santa fee católica lo que dejo de haser por la satisfaçion grande que del dicho raçionero tenia a quien le despacho comisión amplia como del mismo instrumento consta que se remite sin reserva alguna para que en todo el distrito de la provinçia de atacama pudiese conoser de todas las causas de idolatría heregias y de otras quales quiera supersticiones y ritos sin reserbar cosa alguna fiando de su gran talen

\section{[f. $6 \mathrm{v}]$}

to y christiandad el castigo de los complises en dichas culpas y en su conformidad el dicho racionero aviendo resibido la dicha comisión para los efectos de suso referidos se expreso a la execuçion de lo en ella contenido con tan exacto cuidado y diligençia que hiso uno de los maiores frutos del serviçio de Dios que se ha visto oído ni entendido en esta arçobispado pues aviendo corrido toda la provinçia de atacama alta y baxa acompañado de las personas que refiere dicha su petiçion a su propia costa y expensas en que se ocupo mas tiempo de un año descubrió un cresidisimo numero de ídolos en quienes los dichos indios tenían sus adoraçiones de los quales alguna parte de ellos remitió al muy reverendo arçobispo y este testigo los vio remitiendo assi mesmo a los ministros desta falsa ceremonia que venían aser los cavesas prinsipales dellos al convento de los recoletos descalsos desta ciudad para que durantes sus vidas sirbiesen en el eligiendo este medio, por el mas prudente y eficas para destruir tan falso error hasiendo el fruto que tan notorio es en los dichos indios atacamas con su espíritu y ferbor grande del celo de la causa de Dios que tan notorio es en esta provinçia y consta de los autos fechos en esta raçon a que se remite de que resulto en la voluntad del dicho muy reverendo arçobispo tan grande agradesimiento y estimaçion que este testigo le oio desir, diversas veses que a estar en su mano el con digno premio a este fruto se le diera muy a su satisfaçion y tiene por cierto este testigo que a no aver muerto dicho señor arçobispo en aquella ocasión se los solicitara con todo empeño a su propia costa con satisfaçion de aver hecho el dicho raçionero por la suia la dicha extirpacion de idolatrías en que interpuso assi mesmo el trabaxo y riesgos de la vida que se dexan considerar en cuia

\section{[f. $7 \mathrm{r}$ ]}

ocasion de dicha reduçion le sucedió la desgracia de averse quebrado la pierna en la petiçion lleba referido como se lo aviso al dicho 
muy reverendo arçobispo, por donde este testigo lo sabe como tan bien ser el dicho raçionero sacerdote de exemplar vida y costumbres de gran talento prudençia y capacidad y como tal ha dado la buena cuenta que tan notoria es de los puestos y ocupaçiones que ha tenido el visitador eclesiástico comisario de la ynquisiçion y cruzada y vicario y Juez eclesiástico de cuios nombramientos se remite a los títulos y demás instrumentos en esta raçon y esto dixo y a las cartas de agradesimiento y estimaçion que le escribió el dicho muy reverendo arçobispo que fueron de mano deste testigo = preguntado si sabe que el dicho racionero o sus maiores aian de servido en algo a su magestad = dixo que no le consta cosa alguna de lo que se le ha preguntado sino antes lo contrario por averse presiado como se presia de muy fiel y leal vassallo de su magestad y que en crédito de su Real serviçio expondrá su vida $\mathrm{y}$ asienda en las ocasiones que se le ofresieren y esto responde = preguntado en que le parese a este testigo podrá ser remunerado el dicho raçionero y si sabe si por raçon de dichos servicios ha sido en algo remunerado dixo que le parece es digno y meres [ed] or por lo que tiene referido que su magestad le honre y aga merced en un asenço de maior estimaçion desta catredal respecto de no aver sido re

\section{[f. $7 \mathrm{v}]$}

munerado en premio de sus grandes servicios con mas de solamente la dicha raçion con cuia renta aun apenas se puede sustentar y que esta es la verdad so cargo del juramento que tiene fecho y que es de hedad de quarenta años y no le tocan las generales de ley y lo firmo y el dicho oidor lo señalo

\section{Miguel de chalar [rubricado]}

Ante mi

Joseph Giron [rubricado]

En dicho dia y año para la dicha ynformasion el dicho señor oidor hiso pareser ante si al maestro don Ignacio de sepeda y Toledo cura venefiçiado del valle de coroncota del qual se resibio juramento por dios nuestro señor in verbo sacerdotis puesta la mano en el pecho so cargo del qual prometió desir verdad y siendo preguntado por el tenor del dicho memorial dixo = que ha catorse años que conose al dicho raçionero en las provinçias de atacama donde estubo este testigo y vio y comunico al dicho raçionero y fue este testigo a la dicha provinçia en ocasión que el dicho raçionero estaba ocupado con grande vigilançia y zelo fervoroso en la extirpaçion de la idolatría y vio este testigo al dicho racionero que en compañía de dies o doçe personas que llebo en su compañía a quienes sustentaba a su costa andubo por toda aquella provinçia por muy fragosos y difíciles caminos inquiriendo y rastreando los ídolos y en esto mediante su cuidado junto muchos dellos y convocando los yndios de la provinçia para un dia seña

\section{[f. 8r]}

lado a vista de toda ella aviendola llegado el dia que señalo después de averles predicado con grande espíritu poniéndoles los ídolos todos juntos la vana adorasion que usaban y encaminadoles al verdadero conosimiento y significado les elengo[sic] que los demonios les persuadían y aver quitadoles la aprehencion en que el demonio los tenia que por medio de los ydolos les desia que si no los adoraban no tendrían hijos ni fruto en sus cosechas y otros engaños semejantes que después de aver vensido su obstinación y con vivo y ardentissimo espíritu averles aclarado y ilustrado con la Ley del evangelio trato de quemar los ídolos disiendoles para confirmarlos en la fee y quitarles los abusos que tenían en desir que si los maltrataban los tragaría la tierra a lo qual el dicho Licençiado les replicaba diciendoles pues teneis por tan poderosas estas vanas figuras que adorais acabad con ellas que me trague la tierra antes de quemarlas como lo he de hacer y con esto significándoles que el poco poder que tenían era participado de deidad infinitamente superior les quito el abuso y se conosio en sus acciones ya mas llegadas a la verdad el fruto que en sus coraçones avia hecho la predicasion del dicho racionero = para el efecto de quemar los dichos ídolos que se hisiere como mas convieniesse para dar exemplo a los indios el dicho racionero y este testigo y algunos españoles que se hallaron presentes lle

[f. $8 \mathrm{v}$ ]

baron la leña como en sus hombros y poniendo en execucion la quema reparo este testigo en la admiraçion que causo a los indios el ver arder aquellas vanas figuras y coligio el desengaño que tuvieron y lo acertado de la acción en la enmienda de los dichos indios los quales vian que el poder que les avian atribuido era fingido pues los avian visto reducirse a unas zeniças solamente lo que les predicava y rrepetia el dicho racionero y assi mismo sabe que su vida es religiosa y muy exemplar de grandissima caridad asi con sus pobres indios como con los caminantes a quienes socorría con toda la liberalidad y vio este testigo que aun pobre henfermo le dio aun la capa que traia puesta demás de averze dado silla freno y mula y averze aloxado en su aposento mismo preguntado si sabe este testigo que el dicho racionero o sus maiores aian de servido en algo a su magestad dixo que no sabe tal sino que antes a servido a su magestad como dicho tiene preguntado si ha sido remunerado en algo por raçon de dichos servicios y en que le parese podra ser remunerado = dixo que no sabe aia tenido otro premio sino el de la raçon que oy posee y que será digno de que su magestad le honre en una dignidad desta santa iglesia por estar por raçon de sus años, y quebradura de la pierna impedido de ir a otra parte y que esto es lo que sabe y que es verdad so cargo del juramento que fecho tiene en que se afirmo y que es de edad de treinta

[f. $9 \mathrm{r}]$

y siete a treinta y ocho años no le tocan las generales de la ley y lo firmo y el dicho señor oidor lo señalo

Ministro don Ygnacio de cepeda y Toledo [rubricado]

Ante mi

Don Joseph Giron [rubricado] 
En dicho dia mes y año para dicha ynformaçion dicho señor oydor hizo parecer anti si al Maestro Gabriel de Sande clerigo presbítero maestro de Ceremonias en esta Santa Yglesia cathredal metropolitana de la plata, Visitador General que a ssido de este arçobispado de quien aviendose reçevido juramento en forma por dios nuestro señor y una señal de cruz ex in Verbo sacerdotis puesta su mano derecha en el pecho so cargo del qual prometio dezir verdad de lo que supiere y fuere preguntado. Y siendolo por el tenor de el dicho memorial

Dixo que habrá mas de quarenta años que este testigo conose al dicho racionero en la Ciudad de Lima donde le vio y communico con singularidad por ser persona de grandes partes y virtud y sacerdote muy exemplar siendo Amado y venerado de lo principal de aquella ciudad assi eclesiastico como secular.

$\mathrm{Y}$ aviendo dicho Racionero despues de algunos años salido de dicha Ciudad de los Reyes y servido a estas provincias de los Charcas, supo y oyo este testigo siendo Catredatico en la Real Vniversidad de muchas personas que a ella Venian a estudiar que el Muy Reverendo Arçobispo Don Fray Geronimo mendez de Tiedra de felis recordacion enterado de la Virtud Letras y suficiencia de dicho Racionero le eligio y nombro por cura y vicario de la provincia de atacama y assi mismo por Visitador General de dicha provincia procediendo en todo con la puntualidad y exactitud de persona eclesiastica que solo atiende al ajustamiento de su conciencia y el servicio de Dios. Despues de muchos años este testigo yendo en servicio del muy Reverendo Arçobispo Don fray francisco de Borja dios aya de dicha ciudad de la plata por su Credo[i] maestro de ceremonias y Visitador General Visitando dichas provincias de atacama en los años de seiscientos y quarenta =Llegando al puerto de Cubixa Vio que Visito a dicho Racionero y examinando e inquiriendo su modo de proceder y vida asi de officio como a peticion de el Governador de aquellas Provincias Don Pedro ViltiquiViltur califico su modo de proceder a Voz general

\section{[f. gv]}

de españoles e yndios que dicho Racionero en treinta años que avia exercido en aquella provincia de atacama la baja oficio de cura y vicario avia sido tan inculpablemente y con tan christiano proceder que le llamaban el padre de aquella tierra y el que como un apostol avia atendido solo a la redusion de infinitos Yndios que viviendo antes como brutos animales los avia vnido $y$ agregado a la vida politica y christiana y siendo muy pobres y necesitados dicho Racionero, con su pobre caudal y posible los avia alentado y puesto en la ocupacion y exercicio de el tragin de mulas y de la pesquería para asi con su trabaxo socorrer las provincias de Lipes y chichas de pescado de la mar de que totalissimamente carecian dichas provincias en tiempos de adviento $y$ quaresmas $Y$ este testigo como tal visitador Visitando la Capilla y Visse parroquia de Cubixa aviendo echo juntar los yndios pescadores de aquel puerto para la doctrina christiana y examinandolos en todo lo tocante a echiceros viendo quan puntual cuenta daban de el cattesismo y demas cossas de nuestra santa fee admirado dixo muchas vezes que aquello solo procedio de el paternal amor y cuydado de su cura y pastor. Y visitando los ornamentos de dicha capilla hallandolos con tan adelantado aseo y limpiessa dixo dicho Visitador que podrá ser exemplo de muchas iglesias de españoles. Y viendo este testigo que en tan remotas partes dicho Racionero por tantos años avia procedido con tanta justificacion, y siendo el padre de los pasajeros pobres que del Reyno de Chile pasaban a esta de el peru y asi mesmo de los muchos que pomoiva[?] deste peru se van al reyno de Chili y quando los socorría dicho Racionero con cavalgaduras y lo necessario de comida y avio considerando quan solo se hallaba y quan sin premio[?] por no ser conosido de los superiores y prelados por estar en tierras tan remotas haziendo cargo de conciencia propuso le dar muy por menuda cuenta al muy Reverendo arçobispo Don fray Francisco de Borja que dios aya como lo hiço luego que se vio en esta ciudad. Y dicho Reverendo Arçobispo enterado de la verdad y conosiendo las ventajosas partes y procedimientos de dicho Racionero le estimo y honrro con ventajas como constara de muchas cartas que le escribio y en los autos que le despacho nom $[\mathrm{sic}]$

\section{[f. 1or]}

Visitador General de la Ydolatria como constara del titulo que le despacha en cuy[sic] sion y cumplimiento sabe este testigo por averlo oydo a testigos oculares procedio dicho Racionero con tanto zelo y cuydado que por mucho que se encaresca con razones y dilatadas amplificaciones todos quedaran cortas $Y$ limitadas Debiendose a su cuydado vigilancia y atencion la extirpacion de la Ydolatria de aquellas provincias, pues como le consta a este testigo quando las visito por el dicho e ynforme que le hizo el Maestro Juan de Alcala que era el cura de la otra atacama La Alta, se podría temer estar muy arraygada la Ydolatria en aquellas provincias por ser las mas remota y distantes de todo commercio y trato con los españoles y asi mismo en el ultimo retiro de este peru por ser la tierra muy fraagosa y los despoblados grandes y sin el numero de los Yndios cresido y confinar con los yndios calchaquíes gentiles Lo qual aviendolo en todo dicho racionero con el orden y facultad que de el superior tenia puso todo su conato en rastrear y averiguar lo que se le encargaba y como lo principal era entender y saber la lengua de dichos yndios que lo particular es muy dificultosa: con espenssa y alientos de el cielo se puso a estudiarla como la estudio y sabiéndola empesso a comunicar amigablemente algunos yndios que conocía afectos $y$ temerosos de dios y que le senean [sic] amor y voluntad y aunque alcanso de sus dichos algunos vislumbres Valiendose despues de esta jurisdiction y poder de Visitador de la Ydolatria publico vn auto en general para que todos los que supiessen o entendiessen aver en dichas provincias supersticiones echizerias sacrificios y oblaciones a cerros, montes, arboles, animales y que conosiesse o tubiese noticia de algunos sacerdotes o echizeros dentro de tres días de la notificación de aquel auto veniesen a manifestar dezir y declarar lo que supiessen o entendiesen de lo contenido en el con apersevimiento que los que se manifestasen 
y fuesen primeros en descubrirse y declararse con toda piedad y misericordia serian admitidos y perdonados aunque hubiessen cometidos los mayores delitos de el mundo por que los Reveldes y obstinados que ocultandose asi y a los agresores y complices de tan graves delitos, dilatasen el manifestarse o manifestar a los culpados, aviendose averiguado judicialmente ser injustos y culpados los avia de quemar publicamente y abraçar sus haziendas y bienes. Y aviendoles predicado con gran espíritu y doctitud vn sermon en que les dio a entender la gravedad de tales delitos y lo detestable de el crimen de la Ydolatria y con lagrimas lastimadose de el miserable estado en que vivía y declarado como los juezes eclesiásticos con entrañas de padres atendían solo al bien y remedio de las almas que estaba librado en el sacramento de la penitencia y de su parte empeñandoles la palabra

[f. 10v]

y dándoles todo seguro de que a los que se manifestasen y descubriesen desde luego los perdonaba y en adelante premiara por aver dado pricipio a cossa de tanta consideracion fue dios servido de que muchos se manifestasen y descubrieron con que Dicho Racionero tomo Luz de lo que tanto deseaba y Sabiendo de los ydolos y partes do los tenían y veneraban y enterado con verdad de los sacrificios y oblaciones que les hazian en persona entro en las cuevas y lugares ocultos de sus sacrificios y publicamente les quemo y abraço muchos ydolos y castigo a muchos reveldes y obstinados remitiendo a esta ciudad de la Plata al conbento de los descalços de san francisco algunos viejos sacerdotes donde este testigo conocio vno de dichos yndios a quien dios nuestro señor avia hecho tantas misericordias que ya le veneraban por muy exemplar y santa rason por ser muy peni- tente y de fervorossa oración frente todo del gran zelo y piedad de Dicho Razionero. Y últimamente supo este testigo por averlo oydo dezir y exagerar al muy Reverendo Arçobispo Don fray francisco de borja el cuydado solicitud y gastos que avia puesto dicho Racionero[?] en cumplimiento de lo que se le avia encargado tocante a la Ydolatria y como avia llebado en su compañía y a su costa doze hombres españoles para el seguro de su persona y para con mas authoridad y mano obrar lo que obra en razón de cargar ydolatras quemar ydolos y lo demás que hizo en esta razón remitiéndose este testigo a lo actuado $\mathrm{Y}$ a la provicion que esta Real Audiencia despacho a dicho Racionero para que los corregidores de aquellos partidos le diessen e inpartiessen el Real auxilio a que se remite y esto responde

Preguntado si sabe este testigo que dicho Racionero, o sus mayores ayan deservido en algo a su Magestad = Dixo que lo que sabe por aver visto en los papeles, que quan[cortado] de Visitador este testigo vio y examino es que dicho Racionero es persona noble hijo de padres principales su padre Juan de Otal y su madre Juana Casiñere hijos de algo infanzone en el Reyno de Aragon Y por su persona dicho Racionero a servido a su magestad en los officios y cargos que salian fiado y encomendado siendo como tiene declarado este testigo de los mas exemplares curas que a tenido este reyno y el Vicario y juez eclesiástico mas exacto y desentirezado que se a conosido siendo este el officio de comissario de el señor tribunal de la Ynquisicion que exercio por mas de treinta años muy vigilante zeloso y attento $Y$ en el officio de comisario de la santa Cruzada se hubo y paso diligente y cuidadose siendo calificado de sus procedimientos lo honroso con que los superiores le estimaron y alabaron como constava por las cartas misibas a que se remite y esto responde [sic].

\section{$\because$ ANEXO 2}

AGI, Charcas Legajo 96, núm. 21, 1660. Informaciones de José Caro de Mundaca, doctor, Juez eclesiástico y visitador general de todo el arzobispado, fue cura y vicario de San Francisco de Chiu Chiu en la Provincia de Atacama, natural de La Serena (Chile). [Fragmento que incluye el título de Juez Eclesiástico y Visitador General de Idolatrías del Arzobispado otorgado a José Caro de Mundaca, fs. 1or, 14r].

\section{Transcripción de Priscilla Cisternas ${ }^{41}$}

\section{[f. 1or]}

Nos el maestro Don frai Pedro de Oviedo por la graçia de Dios y de la santa sede apostolica Arsobispo de la plata provinçia de los charcas, del peru del consejo de su magestad etcetera Por quanto en su conformidad de lo dispuesto por los santos y sa-

\footnotetext{
${ }^{41}$ Asistente del Proyecto FONDECYT 1100132.
}

grados canones y consillios conviene visitar nuestro arsobispado por tanto atendiendo a la entera satisfaçion y mucha confiançia que tenemos del Dotor Don Joseph Caro de Mundaça y selo santto y a lo mucho que obro y travaxo en destruir Los ydolos que avia en la provinçia de atacama y que concurren en su persona las buenas partes de prudençia consiençia y sufiçiencia que se Requieren y son notorias y nos consta y las de su avilidad y letras de que nos prometemos dara toda buena quenta y a todo lo que por nos lo fuere encomendado y encargado y que con toda felidelidad lo ara y descargara las consençias de su magestad nuestra y suia a cuia consideraçion por la presente en la mexor via y forma que

[f. 10v]

Podemos y de derecho devemos nombramos criamos y elegimos al dicho Doctor Don Joseph Caro de Mundaza por nuestro Juez eclesiastico y visitador general de todo este arsovispado provinçias pueblos y partes del y le damos poder y facultad qual en 
tal casso se rrequiere para que por nos y en nuestro nombre representando nuestra propia persona pueda visitar y visite todos Los curas venefisiados y clerigos del dicho nuestro arsobispado y todas las ygleçias Parroquias y hermitas hospitales y cofradías y los demas lugares pios cuia visita nos yncumba y pertenesca visitando el sagrario y lugar donde esta el Santisimo sacramento Pilas del santo baptismo y crismeras reliquias de santos para ver si estan en lugar desente y con la linpiesa y deçiençia custodia y beneraçion que conbiene $=\mathrm{Y}$ para que pueda visitar $\mathrm{y}$ visite los altares y capillas oratorios aras y corporales caliçes custodias y hornamentos y las demas cosas pertenesientes al culto divino

\section{[f. 11r]}

y para que haga traer y execivir ante si todos los testamentos y codicilios y saver si estan cumplidos en lo que toca a mandas pias y haser executar y cumplir luego los que no lo estubieren y para que asimismo bea los Libros de los bautisados y muertos desposados y padron de confeçados ver si estan escritos por el horden que les esta dado a los dichos curas y para que haga cumplir y executar Las constituçiones sinodales de este arsobispado la qual dicha visita general hara y prosiguira conforme a lo dispuesto por el santo consilio de trento y limense del año de ochenta y tres y por las dichas constituçiones horden y forma que en semexantes visitas suelen aver que todo lo dejamos a la buena dispuçision del dicho Doctor Don Joseph Caro de Mundaça y asimismo le damos la dicha comission y poder como nuestro visitador general para que exsamine a los dichos curas venefeçiados y clerigos, asi en las lenguas de los naturales como

\section{[f. 11v]}

en materias morales casos de consiençia y sacramentos y en el desir misas y seremonias della y a los que no hallare con la sufisençia devida los suspenda por el tiempo que le pareçiere y les pida los títulos de sus hordenes grados y benefisios dimisorias y lisençias con que binieron a estos Reinos $=$ y otro si le damos poder y facultad para que pueda haçer vsar y exerser todo lo demas que por derecho vso y costumbre pertenesca al officio de tal nuestro bisitador general tan cumplidamente como lo an hecho vsado y exersido los demas bisitadores de este arçobispado y le damos poder y facultad para que lleve todos los derechos y emolumentos que como a tal nuestro visitador general le pertenesieren y para que pueda cobrar los de las personas que los debieren prosediendo en todas las causas ceviles y criminales pertenesientes a la Juridision eclesiastica asi de ofisio que no estubieren sentensiadas Las concluia y fenesca determinandolas difinitivamente otorgando las apelaçiones

\section{[f. 12r]}

que por las partes se ynterpusieren siendo en tiempo y forma para ante nos porvenir en grado y las que no Le tubieren ni se allaren, con este recurso las lleve a devida execusion con efecto aplicando las condenasiones que hiçiere la mitad para gastos de la guerra que su magestad tiene contra enemigos de nuestra santa fee catolica por ser conforme a sus reales cedulas y la otra mitad quede a la dispuçision del dicho nuestro bisitador y por la misma raçon tomara quentas a los dichos bicarios de las causas que ante ellos sean fulminado en que aya preferido condenaçion y si para asentarla an tenido Libro y lo que constare lo cobre dellos y de sus bienes por todo rigor de derecho para que se acuda a los efectos a quien pertenese publique y tome rresidençias a todos los bicarios bisite Las fabricas y hospitales guardando la forma del santo consilio de trento procurando si an exersido los sobre dichos y los mayordomos de dichos hospitales bien y fielmente sus ofiçios haçiendoles cargos Resiviendoles sus Justos descargos observando en todo justiçia sobre todo lo qual

\section{[f. 12v]}

y lo concerniente anexo y dependiente pueda el dicho nuestro visitador y Juez eclesiastico proseder y proseda contra todas y qualesquier personas eclesiasticas y seculares de qualquier estado calidad y condision que sean por todo rrigor de apremio y çensuras como no sean las generales y de anatema que por derecho con los demas cassos tocantes a causas matrimoniales y desimales nos están reservadas y se se [sic] ofresiere alguna dellas con el pedimiento nos la rremita o a nuestro provisor $=$ Y por quanto el pecado de la ydolatria es vno de los que Dios nuestro Señor mas se ofende por quitarle la adoraçion devida a su divina magestad y darla a ydolos para que en todo sea servido y se desarraigue este abusso tan asentado entre los yndios en perjuiçio de sus almas cuio rreparo nos yncumbe en horden a ello el dicho Doctor Don Joseph Caro de Mundaça hara la dicha visita y con conosimiento de causa de las ydolatrias superstiçiones hechiserias y brujerías y los lugares para hacerlas los derrivara guacas mochadores y otros en que lo

\section{[f. 13r]}

vsan levantando en los tales Lugares cruzes y a los dogmatistas y maestros de enseñar la dicha ydolatria que no la confesaren y pidieren misericordia la usara con ellos y los absolvera en el fueron ynterior de la consiençia guardando en todo lo que esta dispuesto por el consilio provinsial de Lima y constituçiones sinodales de este arsobispado tocantes a la dicha ydolatria = procurando asimismo saver si los dichos curas benefisiados de dotrinas an guardado y observado las sedulas de su magestad ynsertas en sus titulos çellados por el real patronasgo sobre las diligençias que procuran haser en que al tiempo que disen misa ofrescan por lo qual algunos dejan desirla por ser pobres y si los dichos curas son tratantes o contratantes por el mal exemplo que rresulta de la estimaçion i que deven ser tenidos por rrazon de su dignidad $Y$ si quando estan enfermos los yndios de su curato les van a confesar y procurar que hagan testamento y les dejen la maior parte de sus bienes quedando herederos forsosos y si tienen

\section{[f. 13v]}

hermanos parientes o familiares consigo de que rresulte daño a los yndios de forma que en todo se procure su quietud y con- 
servaçion en horden de lo qual y de todo lo rreferido despache sus mandamientos de prisiones secrestos y enbargos de vienes vendiendolos y rrematandolos en publica almoneda o fuera della despache rreseptorias que para el buen despachado y efecto de la dicha visita y causas que della resultaren convinieren que para todo ello en la forma espaçificada pida se le ymparta el rreal auxilio del braço secular para la execussion de sus autos y sentensias y proseder conforme a derecho en las causas de ynmunidad y fueros de la igleçia nombrar notario fiscal lengua ynterprete y los demas ministros nesesarios ante quien actue y execute sus mandamientos y lo demas que conviniere en el exsamen de testigos y criar otros de nuebo le damos al dicho visitador general tan bastante poder y comission como para el casso se rrequiere y para usar della en todas las partes referidas donde se hallaren aunque ayan en los dichos Pueblos en continuaçion [f. 14r]

de su bisita curas y benefisiados dellos concluidola porque de qualquier causa que se ofreçiere pueda volver en si a aprehender el conosimiento como tal Juez eclesiastico de este arsovispado que para ello en caso nesesario a maior abundamiento le damos la misma comision y cometemos en lo vno y lo otro nuestras beses plenariamente sin que para lo de suso y lo dependiente le falte cosa alguna dada

[al margen] 20 de septiembre 648

En la plata en veinte días del mes de septiembre de mil y seiscientos y quarenta y ocho años firmado de nuestra mano sellada con nuestro sello y rrefrendada de nuestro secretario = el arçobispo de la Plata = Por mandado de su Ilustrisimo el arçobispo mi señor = Licenciado Don Manuel de PeñaLosa y Mansilla secretario.

\section{$*$ Referencias citadas}

\section{Abreviaturas}

ABAS Archivo-Biblioteca Arquidiocesanos Monseñor Taborga, Sección Arzobispal, Sucre

ABNB Archivo Biblioteca Nacional de Bolivia

AGI Archivo General de Indias

\section{Fuentes inéditas}

AGI, Charcas Legajo 96, núm. 21, 1660. Informaciones de José Caro de Mundaca, doctor, Juez eclesiástico y visitador general de todo el arzobispado, fue cura y vicario de San Francisco de Chiu chiu en la Provincia de Atacama, natural de La Serena (Chile).

AGI, Charcas Legajo 97, núm. 5, 1663. Informaciones de oficio y parte de Juan de Alcalá de Olazábal, maestro, fue cura de Atacama es cura y vicario del pueblo de Caiga con parecer de la audiencia del año 1665 .

AGI, Lima, Legajo 263, núm. 9, 1677. Lima, Informaciones de oficio y parte Domingo Suero Leiton de Rivera, presbítero, cura vicario del pueblo de San Francisco de Chio Chio, provincia de Atacama la Baja, testimonio de 1677, certificado en 1668.

AGI, Lima Legajo 520. Expedientes dictados por el Arzobispo de Lima entre 1714 y 1716,31 fs.

ABAS, Sección Arzobispal, Parroquial, San Pedro de Atacama núm. 130, 15 de Noviembre de 1756, 12 fojas. Excomunión de cura de Atacama,
ABNB, EC 1650, núm. 17. Información de los servicios del licenciado Francisco de Otal, racionero de la Catedral de La Plata.

ABNB, E Tierras e Indios, 1757, núm. 50, 7 fs. Representacion de Pascual Sebastian Guacasus Governador de Atacama, sobre que el Corregidor de dicha provincia Don Manuel de Baldivieso le hace cargo del tributo de catorce indios. La Real Audiencia, ordeno de haber lugar al expresado cargo.

\section{Fuentes publicadas}

ARRIAGA, J. de, 1999 [1621]. La Extirpación de Idolatrías en el Pirú (1621). Estudio preliminar y notas de Henrique Urbano. Centro de Estudios Regionales Andinos Bartolomé de Las Casas, Cusco.

ABNB, Correspondencia. Año 1591, VII, 19, núm. 417. Atacama la Grande. Carta informativa del capitán Juan Segura, Corregidor y Justicia Mayor de Atacama, sobre el pescado que los indios del puerto de Magdalena llevan a Potosí. Transcripción de José Luis Martínez 1985, Cuadernos de Historia 5: 167-171.

ABNB C. 1638, III, 22 núm. 1455, 2 fs. Carta de Jerónimo de Contreras, corregidor de Atacama, a la Real Audiencia de La Plata, proponiendo las mejores medidas de calmar la sublevación de los indios de dicho lugar. Transcripción de José Luís Martínez, 1992, Estudios Atacameños 10: 74 .

AGI Charcas, Legajo 92, 105 fs. Probanza de Méritos de Francisco de Otal. Transcripción de Victoria Castro. En De Ídolos a Santos, Evangelización y religión andina en los Andes del sur, V. Castro, 2009. 
Fondo de Publicaciones Americanistas, Universidad de Chile / Centro de Investigaciones Diego Barros Arana / DIBAM, Santiago.

AGI Patronato 188 núm. 4, 4 fs. año 1557. Expediente sobre lo actuado a petición de Juan Velázquez Altamirano por haberse apaciguado los indios del valle de Atacama en el Perú. Transcripción de José Luis Martínez, 1992, en Estudios Atacameños 10: 12-15.

BERTONIO, L. 1984 [1612]. Vocabulario de Lengua Aymara. CERES / IFEA/MUSEF, Cochabamba.

GONZÁLEZ HOLGUíN, D. 1952 [1608]. Vocabulario de la lengva general de todo el Perv llamada Lengua Qqichua o del Inca. Edición del Instituto de Historia, Universidad Mayor de San Marcos, Lima.

LARRAGA, Fray F. 1780 . Promptuario de la Theología Moral, $3^{a}$ edición reformada y corregida por Don Francisco Santos y Grosin. Imprenta de Manuel Martín, Madrid.

MÉNDEZ DE TIEDRA, J. 2002. Constituciones del I Sínodo Platense (1619-1620). Transcripción y edición de Josep M. Barnadas. ABAS, Sucre.

PACHECO, B. 1760. Suma Moral escrita en breve compendio. Imprenta de los herederos de la viuda de Juan García Infanzón, Madrid.

POLO DE ONDEGARDO, J. 1916 [1571] Informaciones acerca de la Religión y Gobierno de los Incas, (1571), Seguidas de las Instrucciones de los Concilios de Lima. Colección de Libros y documentos referentes a la Historia del Perú, Tomo III. Imprenta y Librería Sanmarti y Ca., Lima.

REAL AUDIENCIA DE LA PLATA, 2007. Acuerdos de la Real Audiencia de la Plata de los Charcas, Servicios y Méritos, 1582-1693, vol. 10. Corte Suprema de Justicia, Agencia Española de Cooperación Internacional, Archivo y Biblioteca Nacionales de Bolivia, Sucre.

SANTO TOMÁS, Fray D. de, 1951 [1560]. Lexicon o vocabulario de la lengua general del Peru. Edición Facsimilar, Ediciones del Instituto de Historia, Universidad Mayor de San Marcos, Lima.

VAIISSE, Pbo. E., F. HOYOS, y A. ECHEVERRÍA Y REYES 2006 [1896]. Glosario de la Lengua Atacameña. Universidad de Antofagasta, Antofagasta.

VÁZQUEZ DE ESPINOSA, A. 1948 [1629]. Compendio y descripción de las Indias Occidentales. Smithsonian Institution, Washington.

\section{Bibliografía}

ABERCOMBRIE, T. 1986 The Polities of Sacrifice. An Aymara Cosmology in Action. Tesis de doctorado. University of Chicago, Chicago.
Articulación doble y etnogénesis. En Reproducción y transformación de las sociedades andinas siglos XVI-XX. Tomo I, S. Moreno y F. Salomon (Comps.), pp. 197- 212. Ediciones ABYA-Yala, Quito.

ACOSTA, A. 1979. El pleito de los indios de San Damián (Huarochiri) contra Francisco de Avila, 1607. Historiografía y Bibliografía Americanista, vol. XXIII: 1-33. Escuela de Estudios Hispanoamericanos, Sevilla.

1982a. Los doctrineros y la extirpación de la religión indígena en el arzobispado de Lima, 1600-1620. Jahrbuch für Geschichte von Staat, Wirtscharf und Gesellschaft Lateinamerikas, vol. XIX: 60-109.

1982b. Religiosos, doctrinas y excedente económico indígena en el Perú a comienzos del siglo XVII. Histórica, vol. VI (1): 1-34.

1987. La extirpación de las idolatrías en el Perú. Origen y desarrollo de las campañas. A propósito de Cultura andina y represión, de Pierre Duviols, en Revista Andina 1: 171-195.

ASSADOURIAN, C. S. 1972. Integración y desintegración regional en el espacio colonial. Un enfoque histórico. Eure, vol. II (4): 11- 23.

1979. La producción de la mercancía dinero en la formación del mercado interno colonial. El Caso del Espacio peruano, siglo XVI. En Ensayos sobre el desarrollo económico de México y América Latina, 1500-1975. E. Florescano (Comp.), pp. 223-292, Fondo de Cultura Económica, México.

BAKEWELL, P. 1984. Miners of the Red Mountain Indian Labor in Potosí, 1545-1560. University of New México Press, Albuquerque.

BARNADAS, J. M. 1993. Idolatrías en Charcas (1560-1620): Datos sobre su existencia como paso previo para la valoración del tema de su extirpación. En Catolicismo y Extirpación de Idolatrías Siglos XVI-XVIII. Charcas - Chile - México - Perú, G. Ramos, H. Urbano (Comps.), pp. 89-103. Centro de Estudios Regionales Andinos Bartolomé de Las Casas, Cusco.

1997. Fray Bernardino de Cárdenas, extirpador de la idolatría en Charcas (1622-1634). Anuario de la Academia Boliviana de Historia Eclesiástica 3: 47-72.

2004. Extirpación de idolatrías en Charcas: legislación y acción de la iglesia (siglos XVI-XIX). Anuario de Estudios Bolivianos, Archivísticos y Bibliográficos 10: 79-118.

BARTHEL, T. 1986 [1957]. El agua y el festival de primavera entre los atacameños. Allpanchis año XVIII, 28: 147-184. 
BERENGER, J., V. CASTRO y C. ALDUNATE, 1984. Orientación orográfica de las chullpas en Likán: La importancia de los cerros en la Fase Toconce. En Simposio Culturas Atacameñas, XLIV Congreso Internacional de Americanistas, Manchester, B. Bittman (Ed.), pp. 175-220. Instituto de Investigaciones Arqueológicas R. P. Gustavo Le Paige, Universidad del Norte, Antofagasta.

BERNAND, C. y S. GRUZINSKI, 1992. De la idolatría: una arqueología de las ciencias religiosas. Fondo de Cultura Económica, México.

BOUYSSE-CASSAGNE, Th. 2008. Minas del sol, del Inka, y de la gente. Potosí en el contexto de la minería prehispánica. En Minas y metalurgia en los Andes del Sur desde la época prehispánica hasta el siglo XVII, P. Cruz y J. J. Vacher (Eds.), pp. 303-348. Instituto Francés de Estudios Andinos, Sucre.

BRAVO LIRA, B. 1992. La Universidad en la Historia de Chile 16221992. Pehuén Editores, Santiago.

CASASSAS CANTO, J. M. 1974. La Región Atacameña en el siglo XVII. Datos históricos socioeconómicos sobre una comarca de América meridional. Incluye, en apéndice, la transcripción, completa del Libro de Varias Ojas, 1611-1698, de la Parroquia de Chiuchiu. Universidad del Norte, Antofagasta.

CASTRO, N. y J. HIDALGO, 1999. Brujos y brujería en la Atacama colonial. Inorganicidad de una representación ideológica y diseminación de una matriz cultural (Introducción y transcripción del Quaderno sobre barios delitos y supersticiones del corregidor Manuel Fernández, 1749-1753). Estudios Atacameños 17: 91-124.

CASTRO, N., J. HIDALGO, y V. BRIONES, 2002. Fiestas, borracheras y rebeliones (Introducción y transcripción del expediente de averiguación del tumulto acaecido en Ingaguasi, 1777). Estudios Atacameños 23: 77-109.

CASTRO, N. y J. HIDALGO, 2008. Usos del pasado y memoria familiar. Cacicazgo de Tacna. Diálogo Andino 31: 21-43.

CASTRO, V. 1991. Un proceso de extirpación de Idolatrías en Atacama, siglo XVII. Historia y Cultura XX: 131-150, La Paz.

1993. Un proceso de extirpación de idolatrías en Atacama, siglo XVII. En Catolicismo y Extirpación de Idolatrías Siglos XVIXVIII. Charcas - Chile - México - Perú, G. Ramos, Henrique Urbano, (Comps.) 347-366. Centro de Estudios Regionales Andinos Bartolomé de Las Casas, Cusco.

1997. Huacca Muchay Evangelización y Religión Andina en Charcas Atacama La Baja. Tesis de magíster. Universidad de Chile, Facultad de Filosofía y Humanidades, Santiago.
2009. De Ídolos a Santos. Evangelización y religión andina en los Andes del sur. Fondo de Publicaciones Americanistas Universidad de Chile, Centro de Investigaciones Diego Barros Arana, Santiago.

CASTRO, V. y C. ALDUNATE, 2003. Sacred Mountains in the Higlands of the South - Central Andes. Mountain Research and Development 23 (1): 73-79.

CASTRO, V. y V. VARELA (Eds.), 1994. Ceremonias de tierra y agua Ritos Milenarios Andinos. Fondo de Desarrollo de la Cultura y las Artes, Ministerio de Educación y Fundación Andes, Santiago.

CASTRO, V., V. VARELA, M. URIBE, L. ADÁN y C. MERCADO, 1994. Trabajo y fiesta. La Limpia de Canales, en Ceremonia de Tierras y Agua. Ritos Milenarios Andinos. V. Castro y V. Varela (Eds.), pp. 23-71. Fondo de Desarrollo de la Cultura y las Artes, Ministerio de Educación y Fundación Andes, Santiago.

CORDERO FERNÁNDEZ, M. M. 2010. Las Visitas de Idolatrías. Diódesis de Lima. Siglo XVII. Tesis de doctorado, Pontificia Universidad Católica de Chile, Facultad de Historia, Geografía y Ciencias Políticas, Santiago.

CRUZ, P. y P. ABSI, 2008. Cerros ardientes y huayras calladas Potosí antes y durante el contacto. En Minas y metalurgia en los Andes del Sur desde la época prehispánica hasta el siglo XVII, P. Cruz y J. J. Vacher(Eds.), pp. 91-120. Instituto de Estudios Andinos, Sucre.

CUSSEN, C. 2005. The Search for Idols and Saints in Colonial Peru: Linking Extirpation and Beatification. Hispanic American Historical Review 85 (3): 417-448.

DRAPER, L. A. 2000. Arzobispos, canónigos y sacerdotes: Interacciones entre valores religiosos y sociales del clero de Charcas del siglo XVII. Archivo-Biblioteca Arquidiocesanos "Monseñor Taborga”, Sucre.

DUVIOLS, P. 1971. La lutte contre les religions autochtones dans le Péru colonial. "L'Extirpation de L'Idolâtrie" entre 1532 et 1660 . Institut Français d'Etudes Andines, Lima.

1977. La destrucción de las religiones Andinas (Conquista y Colonia). Universidad Nacional Autónoma de México, México.

1986. Cultura andina y represión. Procesos y visitas de idolatrías y hechicerías Cajatambo, siglo XVII. Centro de Estudios Regionales Andinos Bartolomé de Las Casas, Cusco.

ESTENSSORO, J. C. 2003. Del Paganismo a la Santidad. La incorporación de los indios del Perú al Catolicismo 1532-1750. Instituto Francés de Estudios Andinos, Pontificia Universidad Católica del Perú, Lima.

GISBERT, T. 2010. El cerro de Potosí y el Dios Pachacámac. Chungara 42 (1): 169-180. 
GRIFFITHS, N. 1998. La cruz y la serpiente. La represión y el resurgimiento religioso en el Perú colonial. Pontificia Universidad Católica del Perú, Fondo Editorial, Lima.

GRUZINSKI, S. 1991. La colonización de lo imaginario. Sociedades indígenas y occidentalización en el México español Siglos XVI-XVIII. Fondo de Cultura Económica, México.

GUIBOVICH, P. 1993. La carrera de un visitador de idolatrías en el siglo XVII: Fernando de Avendaño (1580?-1665). En Catolicismo y extirpación de idolatrías siglos XVI-XVIII. G. Ramos y H. Urbano (Comps.), pp. 169-240. Centro de Estudios Regionales Andinos Bartolomé de Las Casas, Cusco.

HIDALGO, J. 1978. Incidencias de los patrones de poblamiento en el cálculo de la población del Partido de Atacama desde 1752 a 1804. Las revisitas inéditas de 1787-1792 y 1804. Estudios Atacameños 6: 53-111.

1982. Fases de la rebelión indígena de 1781 en el corregimiento de Atacama y esquema de la inestabilidad política que la precede, 1749-1781. Chungara 9: 192-246.

2004. Historia Andina en Chile. Editorial Universitaria, Santiago.

HIDALGO, J. y N. CASTRO, 1999. Rebelión y carnaval. Ingaguasi (San Pedro de Atacama) 1775-1777. Estudios Atacameños 17: 61-90.

HIDALGO, J. y N. CASTRO, 1998. Fiscalidad, punición y brujerías. Atacama, 1749-1755. Estudios Atacameños 13: 105-135.

HIDALGO, J. y N. CASTRO, 2008. Civilización y Castellanización de las poblaciones indígenas. Audiencia de Charcas, 1770-1780. En La circulación en el Mundo Andino 1760-1860, T. Pereira y A. Ibáñez (Eds.), pp. 43-79. Fundación Mario Góngora, Santiago.

HIDALGO, J., y V. DIAZ, 1985. Cartas de los Obispos de Arequipa sobre los indios del corregimiento de Arica, 1620-1682. Chungara 15: 77-97.

HIDALGO, J., M. MARSILLI y J. AGUILAR, 2012. Carreras eclesiásticas y extirpación de idolatrías: la doctrina de Camiña, Tarapacá, siglo XVII. Chungara. En prensa.

HORTA, H. 2008 Ms. Evidencias arqueológicas y etnohistóricas de la práctica alucinógena en Atacama. Jornadas de Historia Andina. Valparaíso: Universidad de Valparaíso. Manuscrito en poder del autor.

HORTA, H. 2012. Sacrificadores y víctimas. Hacia la definición del estilo circumpuneño en el complejo alucinógeno de la zona atacameña y noroeste argentino. En The Southern Andean Iconograpic Tradition. Dumbarton Oaks Precolumbian Program, Cotsen Ins- titute of Archaeology, State University of New York / Universidad de Chile. En Prensa.

IRIGOYEN L., A. 2008. Un obispado para la familia: Francisco Verdín Molina, prelado de Guadalajara y Valladolid en la segunda mitad del siglo XVII. Historia Mexicana 58 (2): 557-594.

LATCHAM, R. 1938. Arqueología de la Región Atacameña. Prensas de la Universidad de Chile, Santiago.

MARSILLI, M. 2002. God and Evil in the Gardens of the Andean South: Mid-Colonial Rural Religion in the Diocese of Arequipa. Tesis de doctorado, Emory University.

MARTÍNEZ, J. L. 1985. Información sobre el comercio de pescado entre Cobija y Potosí, hecha por el corregidor de Atacama, don Juan Segura (19 de Julio de 1591). Cuadernos de Historia 5: 161-171.

1995. Autoridades en los Andes. Los atributos del señor. Universidad Católica del Perú, Lima.

MELLAFE, R., A. REBOLLEDO y M. CÁRDENAS, 1992. Historia de la Universidad de Chile. Ediciones de la Universidad de Chile, Santiago.

MILLAR, R. 1998. Inquisición y Sociedad en el Virreynato Peruano. Estudios sobre el Tribunal de la Inquisición de Lima. Instituto Riva Aguero, Pontificia Universidad Católica de Perú, Instituto de Historia, Ediciones de la Universidad Católica del Perú, Lima.

MILLONES, L. 1979. Religion and Power in the Andes: Idolatrous Curacas of the Central Sierra. Ethnohistory 26: 243-263.

MILLS, K. 1994. An Evil Lost to View? An Investigation of Post-Evangelisation Andean Religion in Mid-Colonial Peru. Monograph Series, 18. The University of Liverpool, Liverpool.

1997. Idolatry and Its Enemies Colonial Andean Religion and Extirpation, 1640-1750. Princeton University Press.

MURRA, J. 1975. Formaciones económicas y políticas del mundo andino. Instituto de Estudios Peruanos, Lima.

1978. La Organización Económica del Estado Inca. Siglo XXI, México.

PLATT, T., T. BOUYSSE-CASSAGNE y O. HARRIS, 2006. Qaraqara - Charka Mallku, Inka y Rey en la provincia de Charcas (siglos XV$X V I I)$. Historia Antropológica de una confederación aymara. Instituto Francés de Estudios Andinos, Plural Editores, University of St. Andrews, University of London, Inter American Foundation y Fundación Cultural del Banco Central de Bolivia, La Paz. 
PLATT, T. y P. QUISBERT, 2008. Tras las huellas del silencio Potosí, los Inkas y el virrey Toledo. En Minas y metalurgia en los Andes del Sur desde la época prehispánica hasta el siglo XVII, P. Cruz y J. J. Vacher (Eds.), pp. 231-277. Instituto Francés de Estudios Andinos, Sucre.

RAMOS, G. 1992. Políticas eclesiásticas y extirpación de idolatrías: discursos y silencios en torno al Taqui Onkoy. Revista Andina 10 (1): 147-169.

ROSTWOROWSKI, M. 1998. Ensayos de Historia Andina II. Pampas de Nasca, género, hechicería. Instituto de Estudios Peruanos, Lima.

SALAZAR-SOLER, C. 1997. Las Huacas y el conocimiento científico en el siglo XVI: a propósito del descubrimiento de las minas de Potosí. En Saberes y Memorias en los Andes In Memoriam Thierry Saignes, T. Bouysse-Cassagne (Ed.), pp. 237-257. Institut des Hautes Études de l'Amérique Latine / Instituto Francés de Estudios Andinos, París, Lima.
SALOMON, F. 1990. Culto a los ancestros y resistencia frente al Estado en Arequipa entre los años 1748 y 1754. En Resistencia Rebelión y Conciencia Campesina en los Andes siglos XVIII al XX, S. J. Stern, (Comp.), pp. 148-163. Instituto de Estudios Peruanos, Lima.

TÉREYGEOL, F. y C. CASTRO, 2008. La metalurgia prehispánica de la Plata en Potosí. En Minas y metalurgia en los Andes del Sur desde la época prehispánica hasta el siglo XVII, P. Cruz P. y J. J. Vacher (Eds.), pp. 11-28. Instituto Francés de Estudios Andinos, Sucre.

VARGAS, R., s.j., 1951. Concilios Limenses (1551-1772). Tipografía Peruana, Lima.

WACHTEL, N. 1973. Sociedad e ideología ensayos de historia y antropología andinas. Instituto de Estudios Peruanos, Lima.

ZUIDEMA, T. 1995. El sistema de los ceques del Cuzco. Pontificia Universidad Católica del Perú, Lima. 